Research Article

\title{
Research on assessment of surface water quality of Hau river in An Giang province on the basis of physicochemical parameters and zooplankton system
}

\author{
Phu Huynh ${ }^{1 *}$, Ngoc Thao Nguyen Ly ${ }^{1}$, Ngoc Han Huynh Thi ${ }^{2}$, Ngoc Nu Tran ${ }^{3}$ \\ ${ }^{1}$ HUTECH University; h.phu@ @utech.edu.vn; nln.thao@ hutech.edu.vn; \\ ${ }^{2}$ Hochiminh City University of Nature Resources \& Environment; \\ htnhan_ctn@hcmunre.edu.vn; \\ ${ }^{3}$ Researcher: tngocnu043@gmail.com \\ *Correspondence: h.phu@hutech.edu.vn; Tel.: +84-966687548
}

Received: 05 October 2021; Accepted: 28 November 2021; Published: 25 December 2021

\begin{abstract}
Research on water quality assessment of Hau river in An Giang province was conducted in 2019 in the upper Hau river ( $\mathrm{SH}-\mathrm{T})$ and downstream Hau river adjacent to Can Tho $(\mathrm{SH}-\mathrm{H})$ through the following physico-chemical parameters, heavy metals: temperature, $\mathrm{pH}$, Dissolved Oxygen (DO), COD, BOD 5 , Total Suspended Solids (TSS), Nitrate $\left(\mathrm{NO}_{3}{ }^{-}\right.$by N), Phosphate ( $\mathrm{PO}_{4}{ }^{3-}$ by $\left.\mathrm{P}\right)$, Coliform, Arsenic (As), Lead (Pb), Mercury $(\mathrm{Hg})$, Ammonium $\left(\mathrm{NH}_{4}{ }^{+}\right.$by $\left.\mathrm{N}\right)$ and zooplankton system. Research results showed that: (1) Surface water quality in the area showed signs of pollution, DO content: $3.02-5.97 \mathrm{mg} / \mathrm{l}$, lower than the standard ( $\geq 6 \mathrm{mg} / \mathrm{l}$ ); TSS parameters: $35-90 \mathrm{mg} / \mathrm{l}, 1.75-4.5$ times higher than standard; COD: 10-23 mg/l, 1.1-2.2 times higher than standard; BOD 5 : 7-14 mg/l, 1.753.5 times higher than standard; Ammonium: $0.039-1.14 \mathrm{mg} / \mathrm{l}$ higher than standard 1.63 times in March and 3.83 times in September; Coliform: 2.100-24.000 MNP/100ml, not guaranteed well according to QCVN 08-MT:2015/BTNMT (level A1); (2) Surface water quality in the upper Hau river area according to diversity index $\mathrm{H}^{\prime}: 0.91$ in March at "Heavily polluted" and H': 1.89 in September, at "Moderately polluted"; (3) The results of statistical analysis and PCA showed that the water quality parameters had significant differences between the two seasons, the rainy season showed signs of Coliform pollution and TSS more than the dry season.
\end{abstract}

Keyword: An Giang; Water quality; Diversity index H'; Tu Giac Long Xuyen.

\section{Introduction}

An Giang is one of four provinces and cities belongs to the key economic region of the Mekong Delta [1]. This locality is not only a province with a particularly important strategic position in terms of military and defense of the Southwest region; An Giang also has a border with Cambodia nearly $100 \mathrm{~km}$, with an interlaced system of rivers and canals, fertile land, abundant natural resources [2]. All these advantages have contributed to making An Giang become a key agricultural production province of the country. In addition, An Giang is also a strategic agricultural and aquatic product export source, and is the global source of rice and pangasius agricultural products.

In addition to the economic successes, regional water environment has been and is being affected by increasing agricultural, industrial and daily-life wastes. Water pollution is a global problem, not just one country, or any one territory. To take specific measures to protect water resources, it is essential to assess the current state of water quality. Currently, there are 
many methods to assess water quality such as: environmental monitoring, WQI water quality index, modeling, etc. The task of protecting water sources must be based on the results of water quality assessment. In Vietnam, the application of WQI water quality assessment index is quite popular [3-4], when applied in the study area, it shows that the water quality is polluted and needs to be treated appropriately before being put into use. However, besides comparing water quality parameters with QCVN 08-MT:2015/BTNMT-National technical regulation on surface water quality or calculating WQI index, the assessment of water quality pollution needs to be more comprehensive, to recognize pollution trends, the correlation between water quality pollution components, or to be able to assess water quality from species diversity or detection frequency of aquatic organisms. The method of water quality analysis by H' index, statistical analysis and PCA can better meet this requirement.

\section{Materials and methods}

\subsection{Description of study area}

Hau river is one of two distributaries of the Mekong river flowing into Vietnam's territory and flows through Chau Doc, Long Xuyen (An Giang), Vinh Long, Can Tho City, Chau Thanh (Hau Giang), Soc Trang, and flows into the East Sea from Dinh An and Tran De estuaries (Figure 1). For An Giang province, the Hau river is the waterway that goes through the center of the province from upstream to downstream, and is the main source of water and alluvium for the low-lying area of the Long Xuyen Quadrangle in daily life, agricultural production and aquaculture and seafood processing.

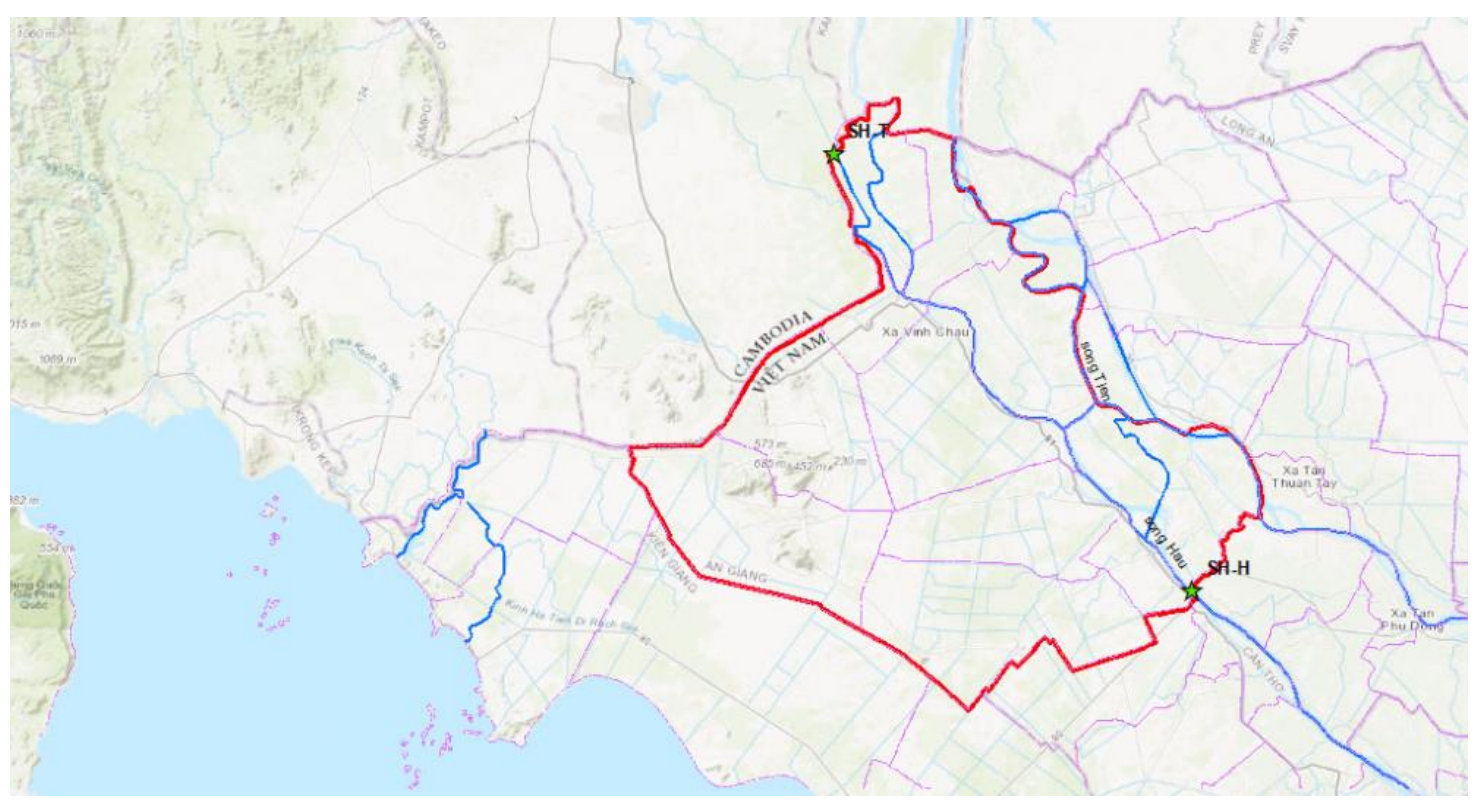

Figure 1. Sampling locations map.

SH-T: the upstream area of Hau river; $\mathrm{SH}-\mathrm{H}$ : downstream area of Hau river

\subsection{Methods of collecting and inheriting data}

Data collection and inheritance about water environment monitoring data in the area, the study of the history and evolution of the aquatic environment to have a process of comparison and assessment.

\subsection{Methods of observation, measurement and analysis}

Monitoring in the upstream area of Hau River, An Phu District (SH-T) and downstream area of Hau River bordering Can Tho $(\mathrm{SH}-\mathrm{H})$, measured parameters of temperature, $\mathrm{pH}, \mathrm{DO}$, 
TSS, COD, BOD 5 , Nitrate $\left(\mathrm{NO}_{3}{ }^{-}\right.$by $\left.\mathrm{N}\right)$, Phosphate $\left(\mathrm{PO}_{4}{ }^{3-}\right.$ by $\left.\mathrm{P}\right)$ and Coliform, Ammonium $\left(\mathrm{NH}_{4}{ }^{+}\right.$by $\left.\mathrm{N}\right), \mathrm{As}, \mathrm{Pb}, \mathrm{Hg}$.

The variation of the flow greatly affects the water quality, so the flow data at the hydrological measurement stations need to be stored for analysis and evaluation of the results. The characteristics of flow change of the Hau river are different in the rainy and dry seasons, and the selection of sampling time in the rainy and dry seasons must take into account the characteristics of the rainfall distribution of the region. Therefore, sampling location, sampling time and frequency of water quality monitoring of Hau River were conducted continuously for 12 months in 2019 at 2 locations: upstream of Hau River (SH-T) and end of Hau river adjacent to $\mathrm{Can}$ Tho $(\mathrm{SH}-\mathrm{H})$ through the physico-chemical parameters, heavy metals.

Research was conducted to assess water quality parameters in the rainy season (July, August, September, October, November, and December in 2019) and the dry season (January, February, March, April, May, and June in 2019), there were 4 observation times each month, especially in December, there were 2 observation times. The zooplankton parameters were performed with a frequency of 2 times/at SH-T in March and September in 2019. The data analysis was performed after removing the outliers of each water quality parameter and the data was normalized to continue the test of statistical significance of variables.

\subsection{Methods of sampling and preservation of samples}

Sampling according to the following standards: TCVN 66631:2011, TCVN 66633:2008, TCVN 59941995, TCVN 66636:2008 and preserving samples according to standard TCVN 66633:2008.

\subsection{Analytical and comparative methods}

The study compared the monitoring results with QCVN 08-MT:2015/BTNMT (level A1)-National technical regulation on surface water quality. In addition, the study conducted statistical analysis and analysis of the main components of water quality parameters to evaluate the spatial trend of pollution at the sampling locations, according to the correlation between physico-chemical parameters, by the rainy season and the dry season.

The study used the Shannon and Weiner diversity index $\left(\mathrm{H}^{\prime}\right)$ to assess the diversity corresponding to the pollution degree of the water environment. The results of the analysis of biological indicators that were compared with the rating scales of Stau et al (1970) are presented in Table 1 by the formula:

$$
\mathrm{H}^{\prime}=-\sum_{\mathrm{i}=1}^{\mathrm{R}} \mathrm{p}_{\mathrm{i}} \ln \mathrm{p}_{\mathrm{i}}
$$

where $\mathrm{p}_{\mathrm{i}}$ is the proportion of characters belonging to the ith type of letter in the string of interest. In ecology, $\mathrm{p}_{\mathrm{i}}$ is often the proportion of individuals belonging to the ith species in the dataset of interest. Then the Shannon entropy quantifies the uncertainty in predicting the species identity of an individual that is taken at random from the dataset.

Table 1. Water Quality Rating by Diversity Index H'.

\begin{tabular}{cc}
\hline Range of ID & Class of water pollution \\
\hline $0<\mathrm{H}^{\prime}<1$ & Heavily polluted \\
$1<\mathrm{H}^{\prime}<2$ & Moderately polluted \\
$2<\mathrm{H}^{\prime}<3$ & Lowly polluted \\
$3<\mathrm{H}^{\prime}<4$ & Slightly polluted \\
$>4-5$ & Good \\
\hline
\end{tabular}


Pearson analysis was performed to establish a correlation matrix and p-values to evaluate the statistical significance of water quality parameters in 2 seasons. Pearson correlation coefficient (symbol $\mathrm{r}$ ), is a test metric that measures the relationship between water quality parameters fluctuating in the continuous range from -1 to +1 ,

where $r=0$ : Two variables have no linear correlation; $r=1 ; r=-1$ : The two variables have an absolute linear relationship; $r<0$ : Negative correlation coefficient. That is, the value of variable $X$ increases, the value of variable $Y$ decreases, and vice versa, the value of variable $\mathrm{Y}$ increases, the value of variable $\mathrm{X}$ decreases; $r>0$ : The correlation coefficient is positive. That is, the value of variable $X$ increases, the value of variable $Y$ increases and vice versa, the value of variable $\mathrm{Y}$ increases, the value of variable $\mathrm{X}$ also increases.

Pearson results are determined to be significant only if and only if the observed significance level is less than the significance level $\alpha=5 \%$. The confirmed degree of correlation with respect to $r$ is as follows:

- If $\mathrm{r}$ is between 0.50 and \pm 1 ; it is called the strong correlation.

- If $\mathrm{r}$ is between 0.30 and \pm 0.49 ; it is called the average correlation.

- If $r$ is less than \pm 0.29 ; it is called the weak correlation.

\subsection{Data processing methods}

The data of the study were processed by using Microsoft Excel software, R software for statistical analysis and principal component analysis.

\section{Results and discussion}

\subsection{Physicochemical parameters}

\subsubsection{Temperature}

The temperature was measured at different times of the year at two locations upstream of the Hau river $(\mathrm{SH}-\mathrm{T})$ and the end of the Hau river $(\mathrm{SH}-\mathrm{H})$ fluctuated between $26.5^{\circ} \mathrm{C}-$ $32.8^{\circ} \mathrm{C}$ and $27.8^{\circ} \mathrm{C}-33.2^{\circ} \mathrm{C}$, respectively. The highest temperature was the 2 nd observation in June at $\mathrm{SH}-\mathrm{T}$ and the $3^{\text {rd }}$ observation in July at $\mathrm{SH}-\mathrm{H}$. The lowest temperature was the $2^{\text {nd }}$ observation in December at SH-T and the $3^{\text {rd }}$ observation in September at SH-H (Figure 2a). In general, the temperature at the monitoring locations was consistent with the temperature of the general environment, without affecting the aquatic life of the area.

\subsection{2. $\mathrm{pH}$}

The results of $\mathrm{pH}$ changes in 2019 by 12 observations at $\mathrm{SH}-\mathrm{T}$ and $\mathrm{SH}-\mathrm{H}$ locations showed that the $\mathrm{pH}$ was relatively stable, ranged from 6.03-7.64 and 6.81-7.86, respectively (Figure 2b). All of these values reached the allowable standards according to QCVN 08MT:2015/BTNMT, leve A1 (68.5), met the quality of water for people's daily life and ensured aquatic life in the area.

\subsubsection{Dissolved oxygen (DO)}

Concentrations of DO at locations $\mathrm{SH}-\mathrm{T}$ and $\mathrm{SH}-\mathrm{H}$ ranged from $3.12-6.39 \mathrm{mg} / \mathrm{l}$ and 3.02-5.97 mg/l, respectively (Figure 2c). Particularly, DO at the location SH-T was the lowest in the $4^{\text {th }}$ observation in November and only $04 / 48$ monitoring times had values that reached the allowed standards according to QCVN 08-MT:2015/BTNMT (leve A1)National technical regulation on quality surface water $(\geq 6 \mathrm{mg} / \mathrm{l})$. The lowest value of DO at the location $\mathrm{SH}-\mathrm{H}$ was the $1^{\text {st }}$ observation in August, the remaining values were lower than QCVN 08-MT:2015/BTNMT. 


\subsubsection{Suspended solids (TSS)}

The monitoring results at SH-T and SH-H locations showed that concentrations of TSS ranged from 31-120 mg/l and 35-90 mg/l, respectively. All of these values exceeded the allowed standards according to QCVN 08-MT:2015/BTNMT, level A1 (20 mg/l) from 1.556 times and 1.75-4.50 times with the highest pollution in the second sampling in September (Figure 2d). Concentrations of TSS in water was mainly affected by the amount of alluvium upstream, plus the amount of soil and rock, waste caused by overflowing rainwater washed into the river, contributing to a significant increase in concentrations of TSS.

\subsubsection{Chemical Oxygen Demand (COD)}

The monitoring results at $\mathrm{SH}-\mathrm{T}$ and $\mathrm{SH}-\mathrm{H}$ locations showed that the COD concentration by the monitoring times ranged from $10-22 \mathrm{mg} / \mathrm{l}$ and $10-23 \mathrm{mg} / \mathrm{l}$, respectively. Except for the 3rd observation in May and June, the values of COD concentration reached the allowed standards according to QCVN 08-MT:2015/BTNMT, leve A1 (10 mg/l); the remaining monitoring times were 1.10-2.20 times higher than the allowed standards, the highest pollution value was the $4^{\text {th }}$ observation in November (Figure 2e).

\subsubsection{Biochemical Oxygen Demand (BOD 5$)$}

The monitoring results showed that the $\mathrm{SH}-\mathrm{T}$ and $\mathrm{SH}-\mathrm{H}$ locations showed that the concentrations of $\mathrm{BOD}_{5}$ by the monitoring times did not reach the allowable standards according to QCVN 08-MT:2015/BTNMT, leve A1 (4 mg/l). The values of $\mathrm{BOD}_{5}$ concentration at $\mathrm{SH}-\mathrm{T}$ ranged from $7-14 \mathrm{mg} / \mathrm{l}$, which were 1.75-3.50 times higher than the standard; the value of $\mathrm{BOD}_{5}$ at $\mathrm{SH}-\mathrm{H}$ ranged from $7-15 \mathrm{mg} / \mathrm{l}$ (Figure 2f), which exceeded the standard by $1.75-3.75$ times.

\subsubsection{Nitrate}

The monitoring results at $\mathrm{SH}-\mathrm{T}$ and $\mathrm{SH}-\mathrm{H}$ locations showed that the concentrations of nitrate $\left(\mathrm{NO}_{3}{ }^{-}\right.$by $\left.\mathrm{N}\right)$ ranged from $0.015-0.340 \mathrm{mg} / \mathrm{l}$ and from undetectable to $0.916 \mathrm{mg} / \mathrm{l}$, respectively. The value of the highest nitrate concentration was the 2 nd observation in November (Figure $2 \mathrm{~g}$ ) but this value still reached the allowable standard according to QCVN 08-MT:2015/BTNMT, leve A1 (2 mg/l).

\subsubsection{Phosphate}

Monitoring results at $\mathrm{SH}-\mathrm{T}$ and $\mathrm{SH}-\mathrm{H}$ locations showed that the values of Phosphate concentrations $\left(\mathrm{PO}_{4}{ }^{3-}\right.$ by $\left.\mathrm{P}\right)$ ranged from undetectable to $0.266 \mathrm{mg} / \mathrm{l}$ and from undetectable to $0.365 \mathrm{mg} / \mathrm{l}$, respectively. The concentrations of Phosphate at the two locations fluctuated continuously through each monitoring period and were not according to the rules, typically at $\mathrm{SH}-\mathrm{T}$, the values of phosphate increased to the highest during the $3^{\text {rd }}$ observation in November; at $\mathrm{SH}-\mathrm{H}$, the values of phosphate was highest during the $4^{\text {th }}$ observation in October (Figure 2h). In general, most of the Phosphate concentrations reached QCVN 08MT:2015/BTNMT, leve A1 (0,1 mg/l). However, at SH-T, there were only 11/48 observations with values exceeding from 1.01-2.66 times and at $\mathrm{SH}-\mathrm{H}$, there were 15/48 observations with values exceeding the allowable standards from 1.03-3.65 times.

\subsubsection{Ammonia}

The monitoring results at $\mathrm{SH}-\mathrm{T}$ and $\mathrm{SH}-\mathrm{H}$ locations showed that the values of ammonium concentration $\left(\mathrm{NH}_{4}{ }^{+}\right.$by $\left.\mathrm{N}\right)$ ranged from $0.039-1.140 \mathrm{mg} / \mathrm{l}$ and from undetectable 
to $1.150 \mathrm{mg} / \mathrm{l}$, respectively. At $\mathrm{SH}-\mathrm{T}$, the values of ammonium exceeded the allowable standards according to QCVN 08-MT:2015/BTNMT, leve A1 (0.3 mg/l), these values were 1.75 times higher in March and 3.80 times higher in September (Figure 2j); At $\mathrm{SH}-\mathrm{H}$, the ammonium values exceeded the allowed standards according to QCVN 08MT:2015/BTNMT, leve A1 (0.3 mg/l), these values were 1.68 times higher in March and 3.83 times higher in September.

\subsubsection{0. $\mathrm{As}, \mathrm{Pb}$ and $\mathrm{Hg}$}

The concentrations of $\mathrm{As}, \mathrm{Pb}$, and $\mathrm{Hg}$ were not found at both locations at all monitoring periods in 2019 (Figure 3), the values of the concentrations of these parameters reached QCVN 08-MT:2015/ BTNMT, leve A1 (As: $0.01 \mathrm{mg} / \mathrm{l} ; \mathrm{Hg}: 0.001 \mathrm{mg} / \mathrm{l} ; \mathrm{Pb}: 0.02 \mathrm{mg} / \mathrm{l}$ ).

\subsubsection{Coliform}

Monitoring results at $\mathrm{SH}-\mathrm{T}$ and $\mathrm{SH}-\mathrm{H}$ locations in 2019 showed that the Coliform bacteria density ranged from 430-24.000 MPN/100 ml and 2.100-24.000 MPN/100 ml, respectively. Except for the $4^{\text {th }}$ observation in January and the $1^{\text {st }}$ observation in July at SH$\mathrm{T}$; and the $1^{\text {st }}$ observation in January, the $3^{\text {rd }}$ observation in May and the $2^{\text {nd }}$ observation in June at $\mathrm{SH}-\mathrm{H}$ (Figure 2i) reached the standard value, the values of Coliform in the remaining observations were higher than QCVN 08-MT:2015/BTNMT, leve A1 (2500 MPN/100 ml) from 1.72-9.60 times.
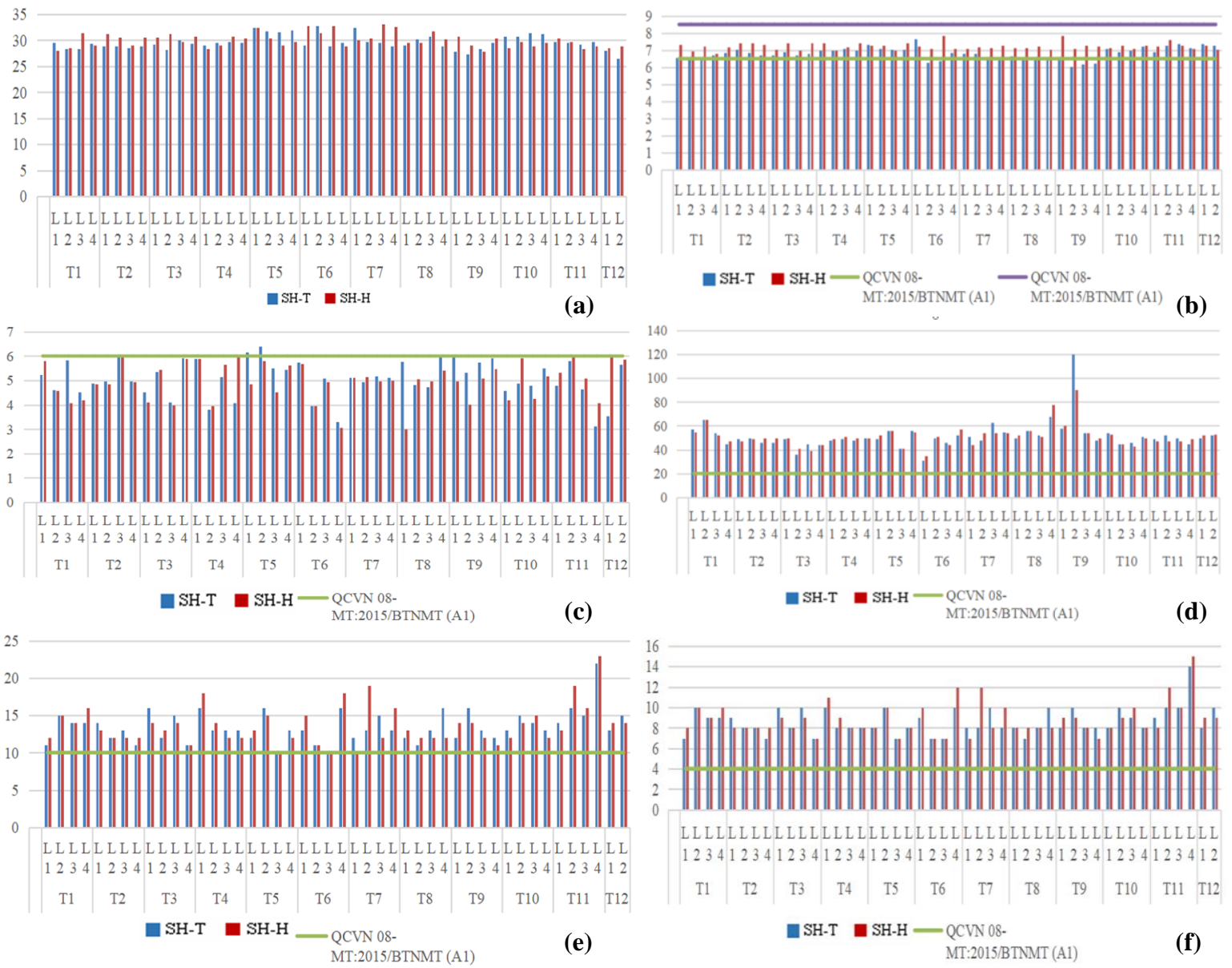

Figure 2. Water quality parameters: (a) Temperature; (b) Values of pH; (c) Concentrations of DO (mg/l); (d) Concentrations of TSS (mg/l); (e) Concentrations of COD (mg/l); (f) Concentrations of $\mathrm{BOD}_{5}(\mathrm{mg} / \mathrm{l})$. 

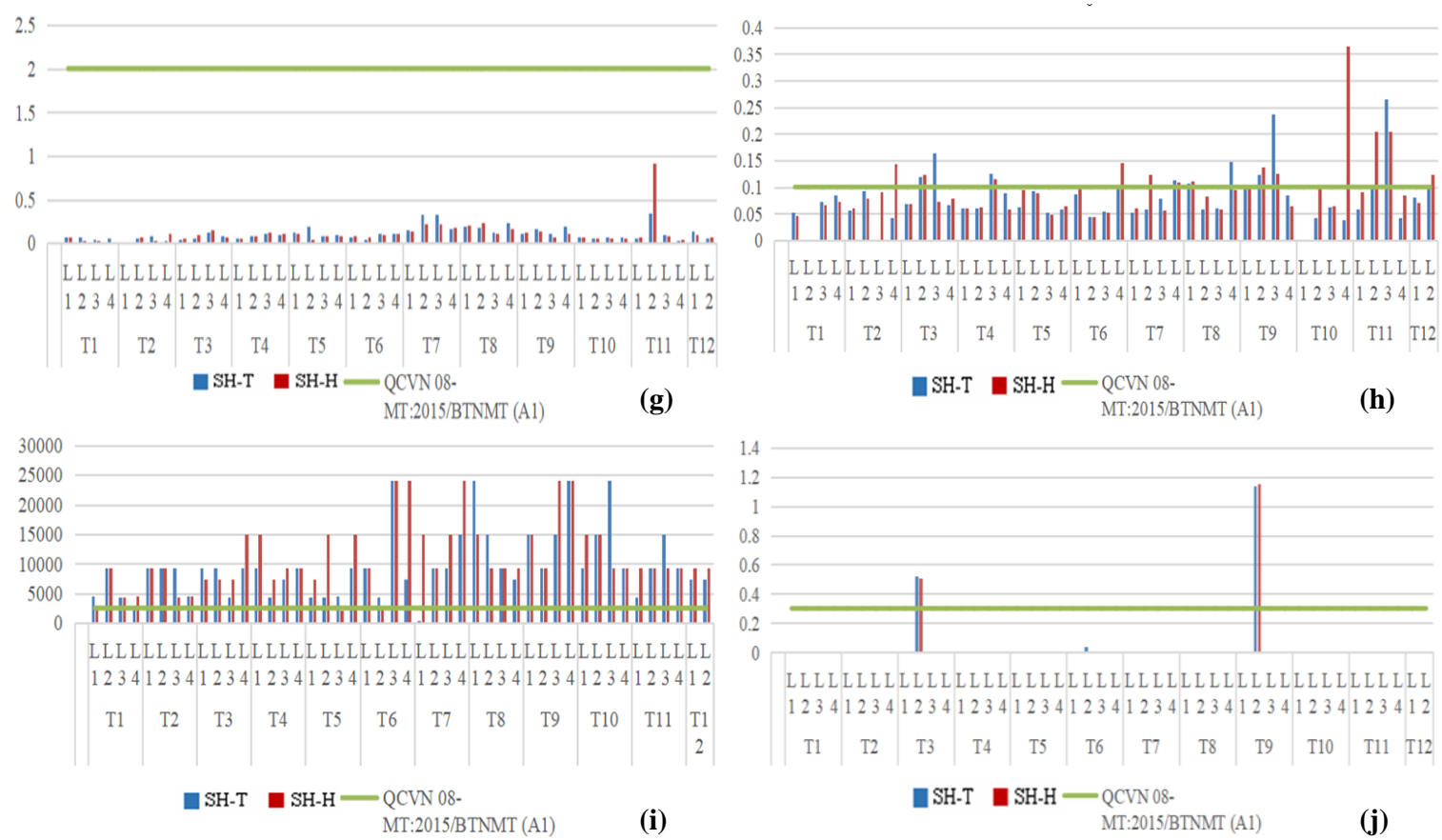

Figure 2. Water quality parameters: (g) Concentrations of Nitrat (mg/l); (h) Concentrations of Phosphate (mg/l); (i) Coliform (MPN/100ml); (j) Concentrations of Ammonia (mg/l) (continute).

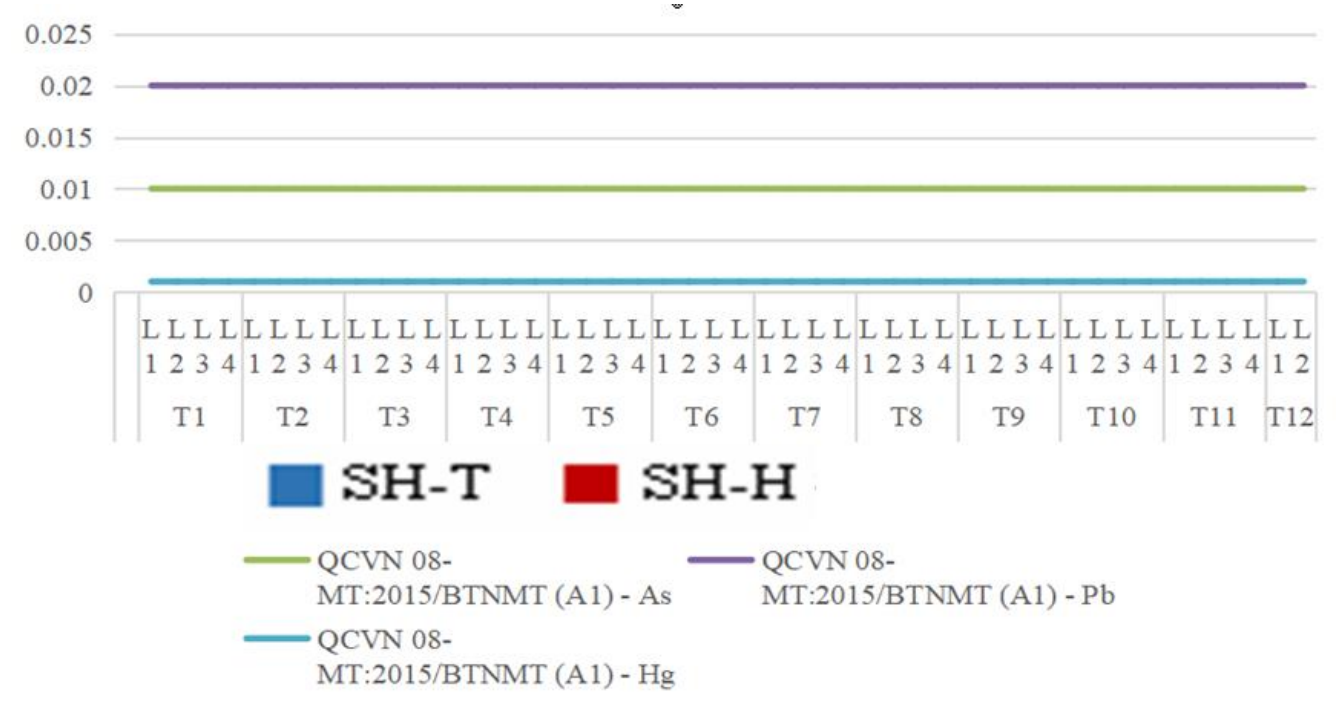

Figure 3. Concentrations of $\mathrm{As}, \mathrm{Pb}, \mathrm{Hg}(\mathrm{mg} / \mathrm{l})$.

\subsection{Components of the zooplankton system}

\subsubsection{Density of zooplankton}

The results of monitoring parameters of phytoplankton in the upstream area of the Hau river in March (dry season) and September (rainy season) in 2019 are as follows:

- Structure of species composition: The composition of zooplankton species had a low diversity, only a total of 18 species belonging to 5 phylums had been identified. The structure of species composition during the year did not change significantly. In the dry season, the study recorded a more diverse species composition than in the rainy season (Figure 4 and Figure 5). 


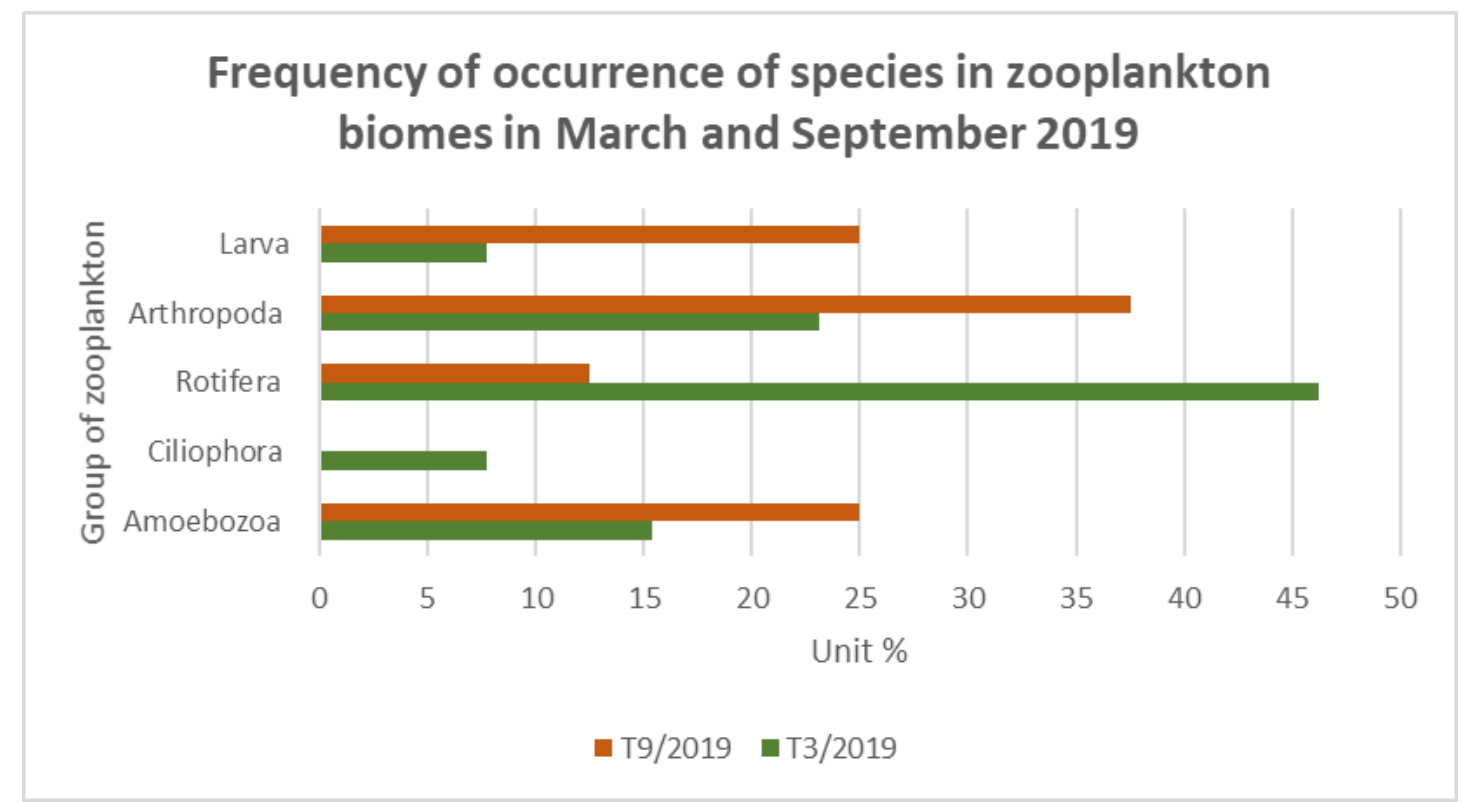

Figure 4. Species composition of zooplankton system at $\mathrm{SH}-\mathrm{T}$ during rainy and dry seasons.

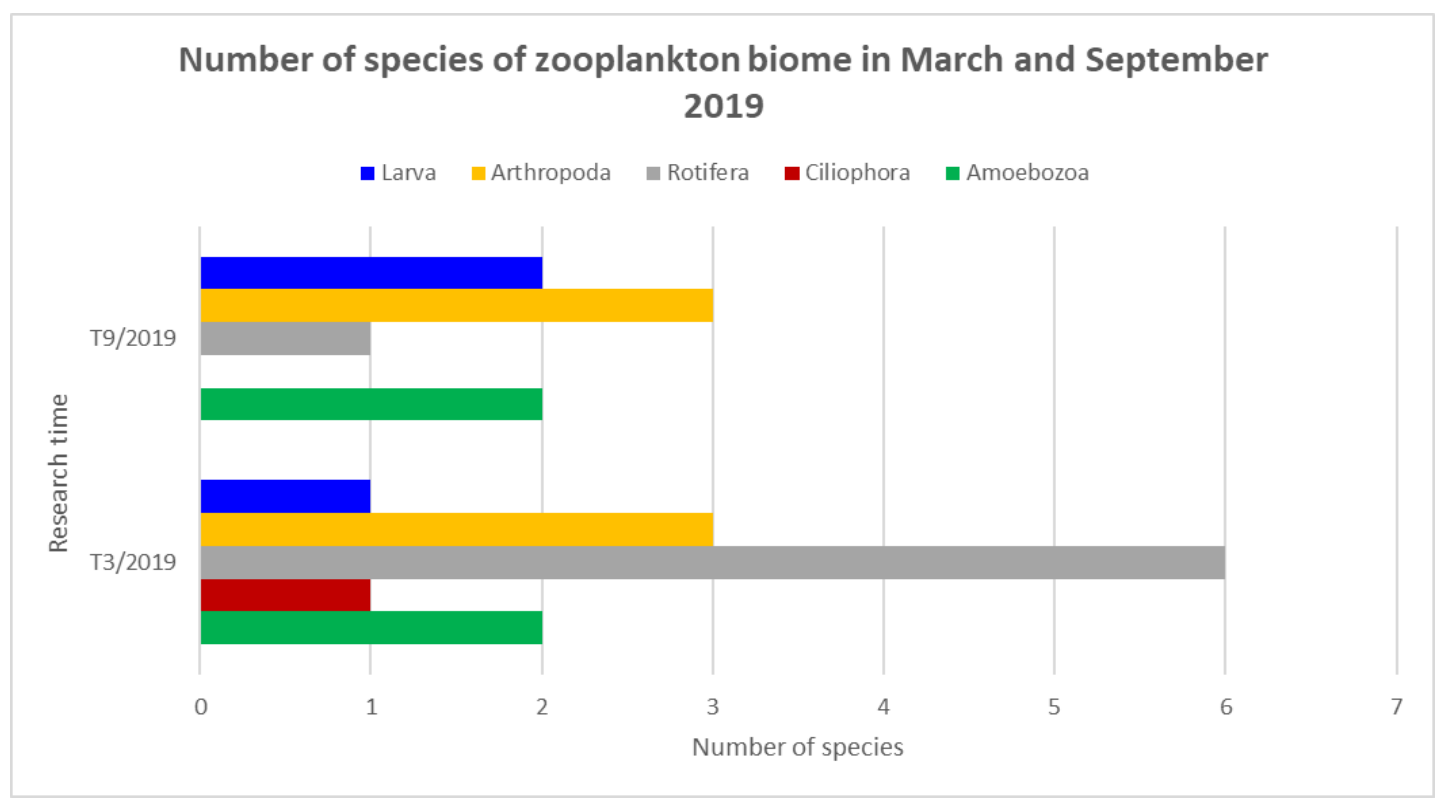

Figure 5. Number of species of zooplankton system at SH-T in rainy and dry seasons.

The comparison between the two observations in 2019 showed that the total number of species in the September monitoring period was reduced compared to the March period (05 species). The fluctuations were concentrated mainly in the Rotifera, which decreased by 5 species; the Ciliophora that decreased by 01 species and the Larval that increased by 1 species; the Arthopoda and Amoebozoa did not have much change.

Amoebozoa, Arthropoda, Larvae appeared in the whole year with a total of 03 species, accounting for $16.7 \%$ of the total number of species present in both observations. The results of two monitoring showed that the zooplankton sysytem in the upper Hau river area (SH-T) in 2019 had seasonal fluctuations, focusing mainly on the group of species adapted to the environment rich in organic matter.

- Individual density and dominant species composition: The species structure and dominant species composition in the upper Hau river area ( $\mathrm{SH}-\mathrm{T})$ were different between the two observations. The number of species and density of individuals in the rainy season decreased significantly compared to the dry season. 
Table 2. Number of species and density of zooplankton system in the upper Hau river area.

\begin{tabular}{ccccc}
\hline \multirow{2}{*}{ Location } & \multicolumn{2}{c}{ Number of species } & \multicolumn{2}{c}{ Density /m } \\
\cline { 2 - 5 } & March 2019 & September 2019 & March 2019 & September 2019 \\
\hline SH-T & 13 & 8 & 867.200 & 6.000 \\
\hline
\end{tabular}

- Individual density: The total number of phytoplankton individuals detected in the upper Hau river (SH-T) area through two observations in 2019 was 867.200 individuals $/ \mathrm{m}^{3}$ and 6.000 individuals $/ \mathrm{m}^{3}$, respectively. The density of cetaceans ranged from 200-720.000 individuals $/ \mathrm{m}^{3}$ in March and from 667-3.333 individuals $/ \mathrm{m}^{3}$ in September.

- Predominant species composition: Paracalanus parvus species of biome Arthropoda predominated with the rate of $83 \%$ in March and Copepoda nauplius species of biome Larva predominated with the rate of $55.6 \%$ in September.

Table 3. The dominant species of the zooplankton system of the upper reaches of Hau river.

\begin{tabular}{ccccc}
\hline \multirow{2}{*}{ Location } & \multicolumn{2}{c}{ March 2019 } & \multicolumn{2}{c}{ September 2019 } \\
\cline { 2 - 5 } & $\begin{array}{c}\text { Predominated } \\
\text { species }\end{array}$ & Rate \% & $\begin{array}{c}\text { Predominated } \\
\text { species }\end{array}$ & Rate \% \\
\hline SH-T & Paracalanus parvus & 83.0 & Copepoda nauplius & 55.6 \\
\hline
\end{tabular}

The clustering by species composition and occurrence frequency of zooplankton communities at SH-T in the rainy and dry seasons were shown above Figure 6 and Figure 7.

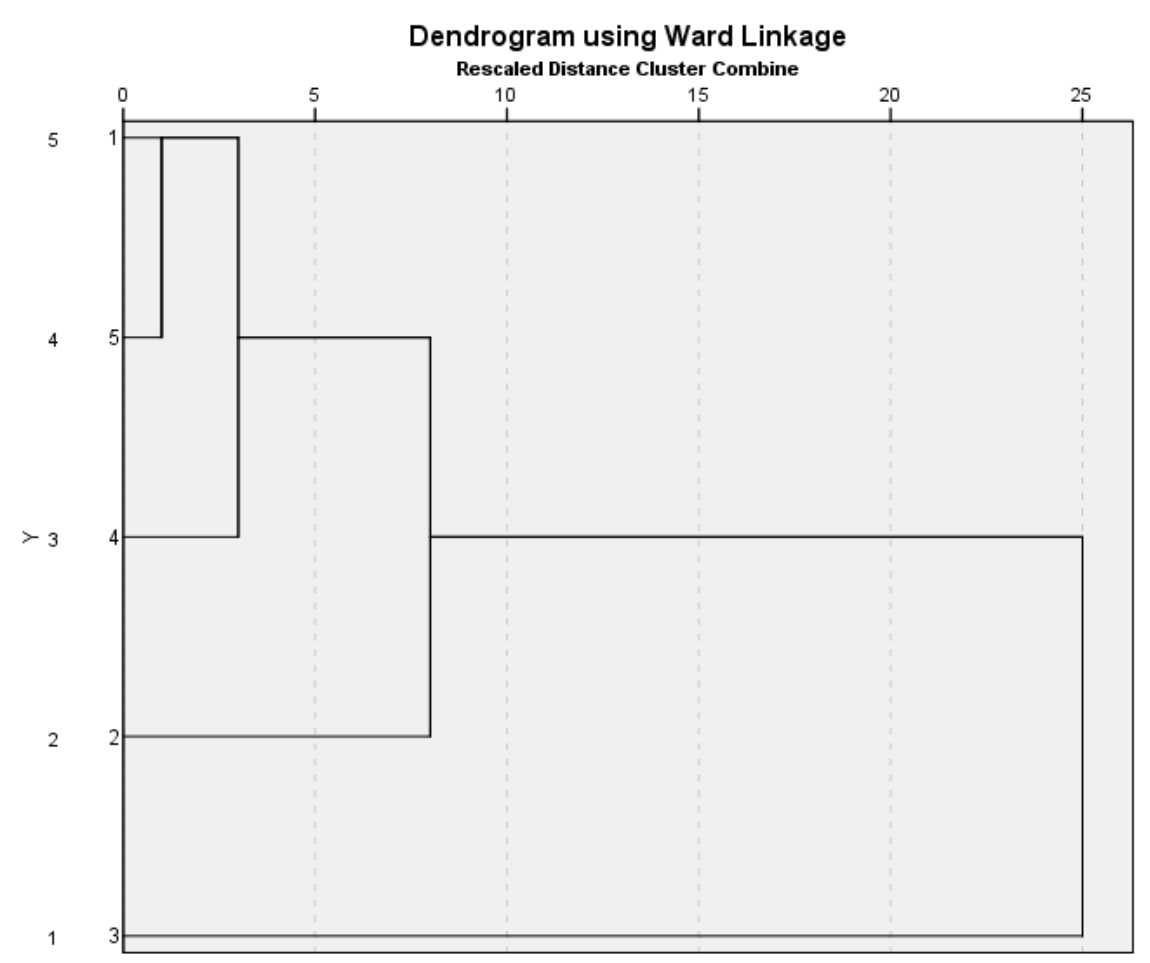

Figure 6. Clustering chart by species composition of zooplankton biome at $\mathrm{SH}-\mathrm{T}$ in rainy and dry seasons. 1. Amoebozoa, 2. Ciliophora, 3. Rotifera, 4. Arthropoda, 5. Larva.

\subsubsection{Diversity index H'}

Calculation results showed that the diversity index H' of the zooplankton in the upstream area of Hau river $\mathrm{SH}-\mathrm{T}$ through two observations in 2019 ranged from 0.91 to 1.89. In which, the $\mathrm{H}^{\prime}$ index in the rainy season was higher than in the dry season, the water quality according to the index H' of the zooplankton tended from "Heavily polluted" to "Moderately polluted" (Table 4). 


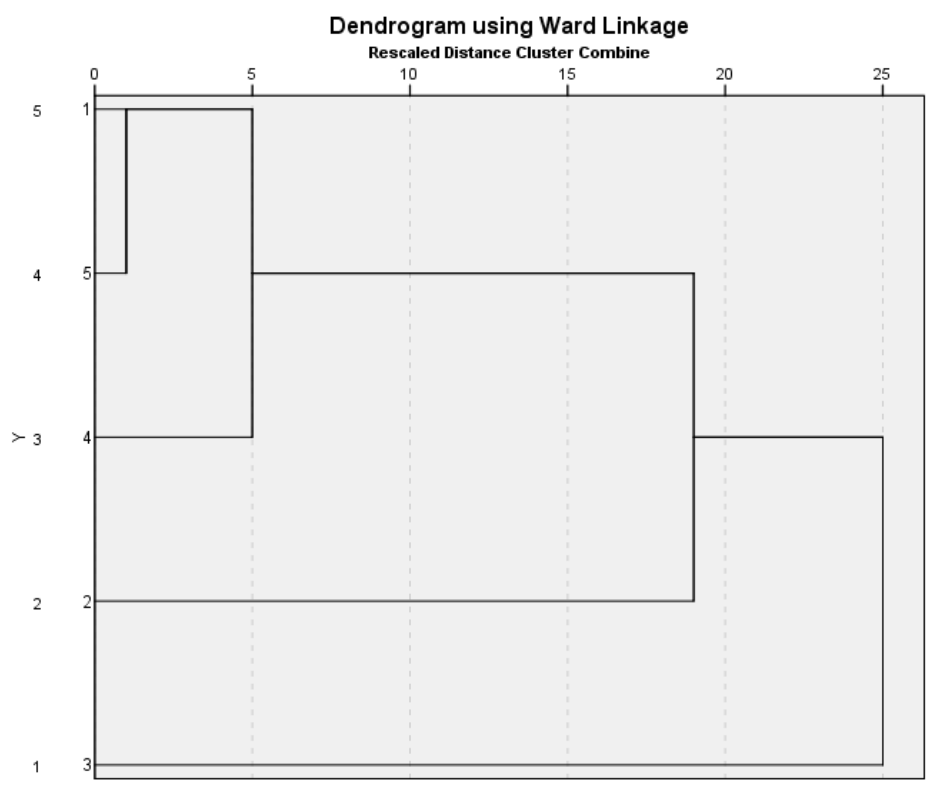

Figure 7. Clustering chart by frequency of zooplankton biomes at SH-T in rainy and dry seasons. 1.Amoebozoa, 2. Ciliophora, 3. Rotifera, 4. Arthropoda, 5. Larva.

Table 4. Diversity index H' of the zooplankton system.

\begin{tabular}{ccccc}
\hline \multirow{2}{*}{$\begin{array}{c}\text { Zooplankton } \\
\text { sysytem }\end{array}$} & $\begin{array}{c}\text { 3-2019 } \\
\text { Diversity } \\
\text { index H' }\end{array}$ & Water quality & $\begin{array}{c}\text { Diversity } \\
\text { index H' }\end{array}$ & Water quality \\
\cline { 2 - 5 } & 0.91 & Heavily polluted & 1.89 & Moderately polluted \\
\hline
\end{tabular}

\subsection{Statistical analysis of water quality parameters}

\subsubsection{Descriptive statistical analysis of the variables}

Because the parameters Ammonium $\left(\mathrm{NH}_{4}{ }^{+}\right.$by $\left.\mathrm{N}\right), \mathrm{As}, \mathrm{Pb}, \mathrm{Hg}$ had low values, most were not found in observations, these parameters were removed and not further analyzed. The results of the descriptive statistics are presented in Table 5.

Table 5. Descriptive statistics of water quality parameters at sampling locations in Hau river in the dry and rainy seasons.

\begin{tabular}{|c|c|c|c|c|c|c|c|}
\hline \multirow[b]{2}{*}{ Parameters } & \multirow[b]{2}{*}{ Unit } & \multicolumn{3}{|c|}{ Dry season } & \multicolumn{3}{|c|}{ Rainy season } \\
\hline & & $\begin{array}{c}\text { Number of } \\
\text { samples }\end{array}$ & $\begin{array}{l}\text { Mean } \\
\text { values }\end{array}$ & $\begin{array}{c}\text { Dtandard } \\
\text { deviations }\end{array}$ & $\begin{array}{c}\text { Number } \\
\text { of } \\
\text { samples }\end{array}$ & $\begin{array}{l}\text { Mean } \\
\text { values }\end{array}$ & $\begin{array}{c}\text { Standard } \\
\text { deviations }\end{array}$ \\
\hline Temperature & ${ }^{\circ} \mathrm{C}$ & 48 & 30,01 & 1.37 & 44 & 29.69 & 1.29 \\
\hline $\mathrm{pH}$ & & 48 & 7.05 & 0.32 & 44 & 7.04 & 0.36 \\
\hline DO & $\mathrm{mg} / \mathrm{l}$ & 48 & 5.00 & 0.81 & 44 & 5.04 & 0.74 \\
\hline TSS & $\mathrm{mg} / \mathrm{l}$ & 48 & 48.79 & 6.60 & 44 & 53.07 & 8.68 \\
\hline COD & $\mathrm{mg} / \mathrm{l}$ & 48 & 13.17 & 2.01 & 44 & 14.02 & 2.70 \\
\hline $\mathrm{BOD}_{5}$ & $\mathrm{mg} / \mathrm{l}$ & 48 & 8.52 & 1.22 & 44 & 9.02 & 1.70 \\
\hline Nitrat & $\mathrm{mg} / \mathrm{l}$ & 48 & 0.08 & 0.04 & 44 & 0.15 & 0.15 \\
\hline Phosphate & $\mathrm{mg} / \mathrm{l}$ & 48 & 0.07 & 0.03 & 44 & 0.10 & 0.07 \\
\hline Coliform & MPN/100ml & 48 & 8.28 & 4.50 & 42 & 12.78 & 5.44 \\
\hline
\end{tabular}


The descriptive statistics of the data in Table 5 showed that the average value of water quality parameters did not change much between the two seasons. The parameters with relatively clear diagnostic deviations are Temperature, TSS, COD, $\mathrm{BOD}_{5}$ and Coliform, and most of these parameters in the rainy season have higher standard deviations than in the dry season. However, to determine whether the difference in standard deviations of the variables in the 2 seasons is due to random factors from the data or due to the actual difference of the environment in the 2 seasons (such as influenced by runoff, rain, washout, tides and seasonal flow characteristics, etc), the study assessed the statistical significance of the water quality difference according to each pollution parameter.

3.3.2. Evaluation of the statistical significance of the variation of water quality by each parameter between the two seasons

\section{a. Shapiro-Wilk test}

To choose a method to test the statistical significance of water quality parameters, the study conducted to determine the normal distribution of water quality parameters. The number of samples in the rainy and dry seasons was $<50$, so the study applied the ShapiroWilk test with the significance level of $5 \%$ to determine the normal distribution of water quality parameters. The results of the Shapiro-Wilk normal distribution test are presented in Table 6 and the pattern of the distribution's evolution is shown in the Histograms in Figures 16 and 17 (Values of water quality parameters with a normal distribution will have Histograms with a symmetric bell-shaped normal curve with the highest frequencies in the middle and the lower frequencies on the sides. Mean and median values are close to each other and the slope is close to zero).

Table 6. Shapiro-Wilk normal distribution test results of water quality parameters in rainy and dry seasons.

\begin{tabular}{cccc}
\hline Number & Parameter & p-value in dry season & p-value in rainy season \\
\hline 1 & Temperature & $1.53 \mathrm{E}-02$ & $6.64 \mathrm{E}-01$ \\
2 & $\mathrm{pH}$ & $7.22 \mathrm{E}-01$ & $4.23 \mathrm{E}-03$ \\
3 & $\mathrm{DO}$ & $6.03 \mathrm{E}-02$ & $4.63 \mathrm{E}-03$ \\
4 & $\mathrm{TSS}$ & $1.22 \mathrm{E}-01$ & $1.05 \mathrm{E}-09$ \\
5 & $\mathrm{COD}$ & $4.48 \mathrm{E}-02$ & $2.56 \mathrm{E}-05$ \\
6 & $\mathrm{BOD}_{5}$ & $2.87 \mathrm{E}-04$ & $1.13 \mathrm{E}-06$ \\
7 & Nitrat & $1.53 \mathrm{E}-01$ & $2.24 \mathrm{E}-09$ \\
8 & Phosphate & $6.02 \mathrm{E}-05$ & $9.18 \mathrm{E}-06$ \\
9 & Coliform & $5.14 \mathrm{E}-05$ & $3.50 \mathrm{E}-14$ \\
\hline
\end{tabular}

The results of the Shapiro-Wilk normal distribution of the parameters from Table 6 showed that:

- Dry season: $\mathrm{pH}, \mathrm{DO}, \mathrm{TSS}$, and Nitrate parameters were normally distributed with $\mathrm{p}-$ value > 0.05; Temperature, $\mathrm{COD}, \mathrm{BOD}_{5}$, Phosphate and Coliform parameters were not normally distributed because they had $\mathrm{p}$-value $<0.05$.

- Rainy season: Temperature parameter was normally distributed with $\mathrm{p}$-value $>0.05$; $\mathrm{pH}, \mathrm{DO}$, TSS, Nitrate, COD, BOD 5 , Phosphate and Coliform parameters were not normally distributed because they had $\mathrm{p}$-value $<0.05$.

- Most of the water quality parameters did not have a normal distribution, so the study chose a non-parametric test method (the Wilcoxon signed-rank non-parametric test with the level of statistical significance $\alpha=5 \%$ ) to determine the statistical significance of the water quality parameters in 2 seasons. 
b. Wilcoxon signed-rank test

The results are shown in Table 7.

Table 7. Wilcoxon signed-rank non-parametric test results.

\begin{tabular}{cccccc}
\hline Number & Parameters & $\begin{array}{c}\text { Number of } \\
\text { samples in dry } \\
\text { season }\end{array}$ & $\begin{array}{c}\text { Number of } \\
\text { samples in rainy } \\
\text { season }\end{array}$ & p-value & $\begin{array}{c}\text { Statistically } \\
\text { significant* }\end{array}$ \\
\hline 1 & Temperature & 48 & 44 & $2.1 \mathrm{E}-01$ & No \\
2 & $\mathrm{pH}$ & 48 & 44 & $9.9 \mathrm{E}-01$ & No \\
3 & $\mathrm{DO}$ & 48 & 44 & $1.0 \mathrm{E}+00$ & No \\
4 & $\mathrm{TSS}$ & 48 & 44 & $1.4 \mathrm{E}-02$ & Yes \\
5 & $\mathrm{COD}$ & 48 & 44 & $2.3 \mathrm{E}-01$ & No \\
6 & $\mathrm{BOD} 5$ & 48 & 44 & $5.7 \mathrm{E}-01$ & No \\
7 & Nitrat & 48 & 44 & $1.9 \mathrm{E}-04$ & Yes \\
8 & Photphat & 48 & 44 & $1.4 \mathrm{E}-01$ & No \\
9 & Coliform & 48 & 44 & $6.1 \mathrm{E}-06$ & Yes \\
\hline
\end{tabular}

*After comparing the $\mathrm{p}$-value with $\alpha=5 \%$.

According to the results of the Wilcoxon signed-rank non-parametric test, the water quality parameters had significant differences and are statistically significant between the two seasons, namely TSS, Nitrate and Coliform, and all three parameters in the rainy season had higher concentration values than in the dry season. Parameters with no statistically significant differences between the two seasons were Temperature, $\mathrm{pH}, \mathrm{DO}, \mathrm{COD}, \mathrm{BOD}_{5}$ and Phosphate. Thus, in general, Hau river water quality in the rainy season showed more signs of pollution of suspended solids and harmful bacterias than in the dry season. The cause could due to natural origin such as phenomenon of erosion, erosion, geological structure or under the influence of human activities, production, untreated wastewater, excessive agricultural production, etc. For these reasons caused many bad effects leading to pollution in water by the process of decomposition of organic compounds, high concentration of Coliform bacteria in water; TSS concentration in water was mainly affected by the amount of alluvium flowing back from upstream, plus a large amount of soil, rock, and waste due to overflowing rainwater washed into the river, contributing to a significant increase in TSS concentration.

\subsubsection{Correlation analysis}

The results of Pearson matrix analysis are shown in Figure 8 and Figure 9.

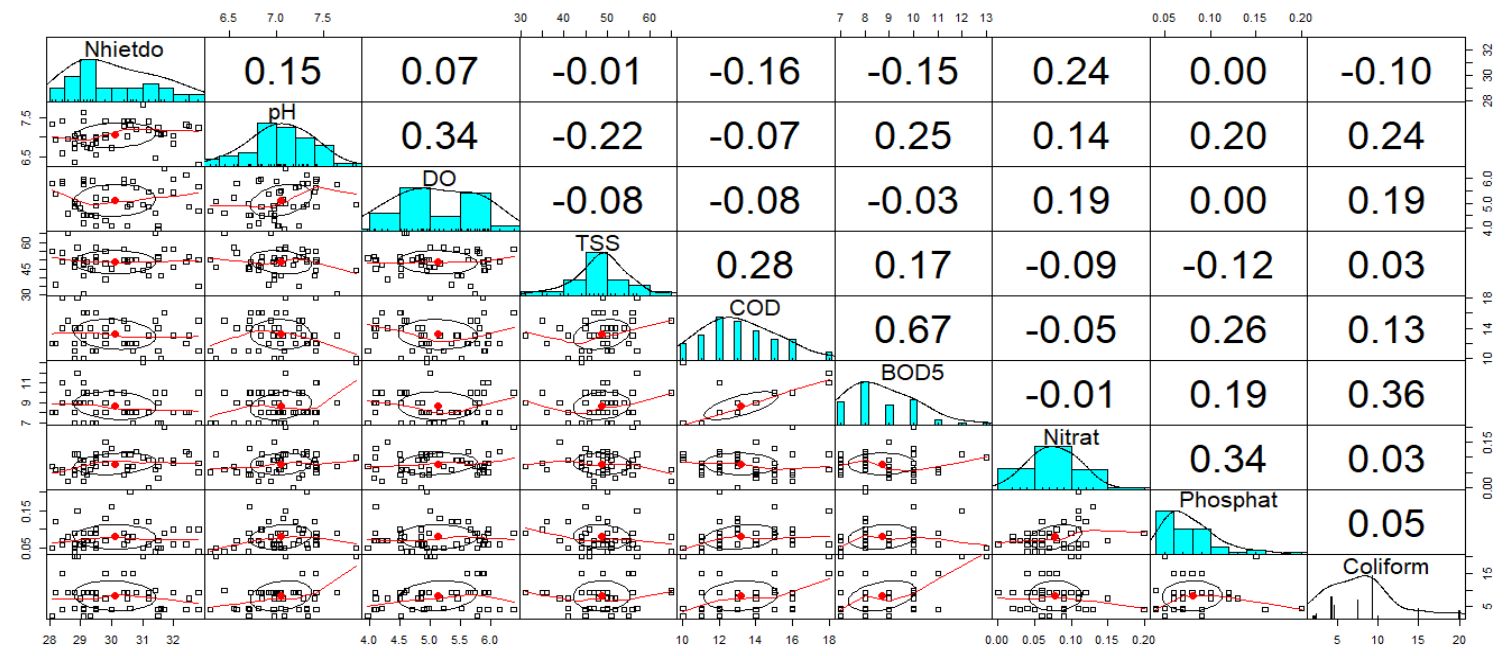

Figure 8. Correlation analysis matrix between water quality parameters in dry season. 


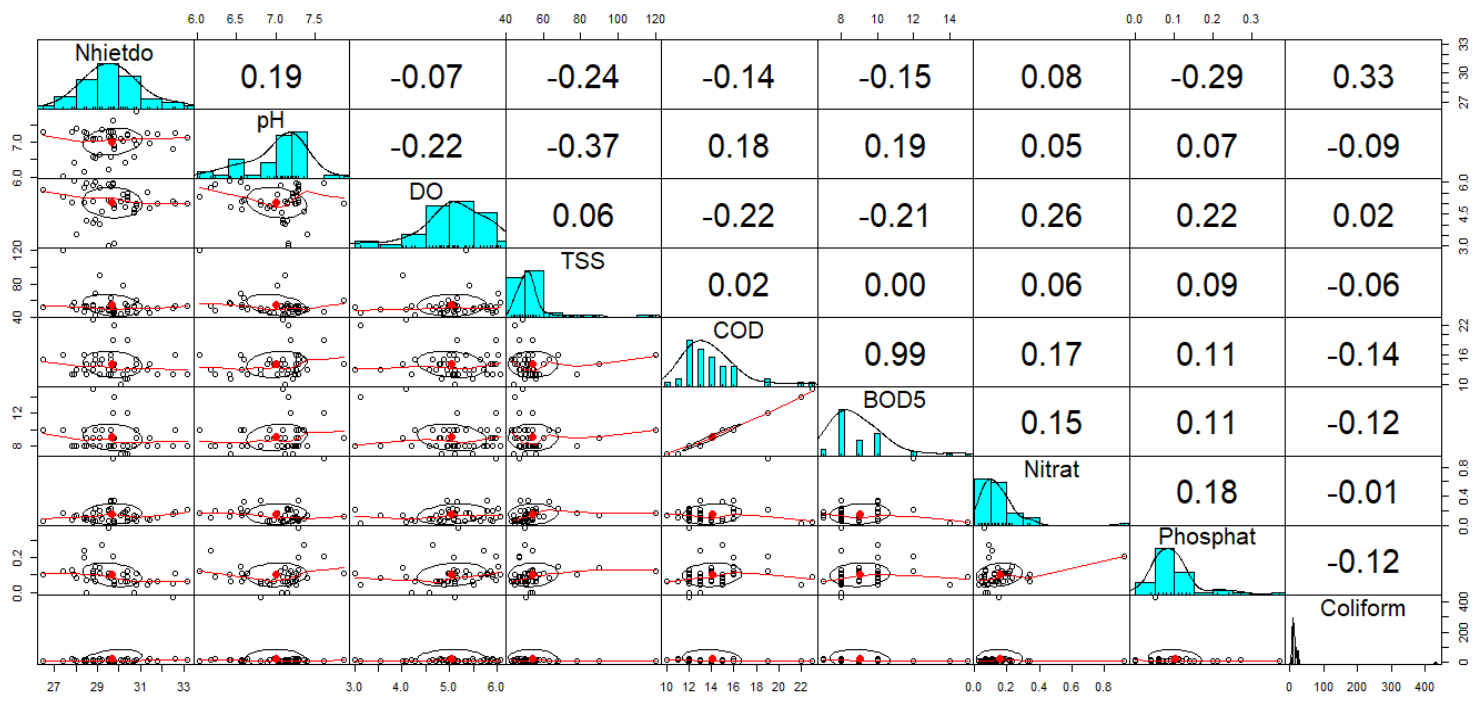

Figure 9. Correlation analysis matrix between water quality parameters in rainy season.

The results of correlation analysis of water quality parameters in Figure 8 and Figure 9 showed that the correlation coefficients between water quality parameters in the dry season were much larger in absolute values than in the rainy season, so water quality parameters in the dry season had a stronger correlation than in the rainy season.

- In the dry season: the pair of parameters $\mathrm{COD}$ and $\mathrm{BOD}_{5}$ had a strong correlation $(\mathrm{r} \geq$ 0.5). Meanwhile, the pairs of parameters $\mathrm{pH}-\mathrm{DO}$, Nitrate-Phosphate, $\mathrm{BOD}_{5}$-Coliform had an average correlation $(0.3 \leq \mathrm{r}<0.5)$. Parameter pairs $\mathrm{pH}$-Temperature, DO-Temperature, TSS-COD, TSS-BOD 5 , pH-BOD 5 , Nitrate-Temperature, Nitrate-DO, Nitrate-pH, pHPhosphate, COD-Phosphate, $\mathrm{BOD}_{5}$-Phosphate, $\mathrm{pH}$-Coliform, DO-Coliform, CODColiform, Phosphate-Coliform had a weak correlation $(\mathrm{r}<0.3)$. The remaining parameter pairs: TSS with $\mathrm{pH}$ and DO; COD with Temperature, $\mathrm{pH}$ and $\mathrm{DO} ; \mathrm{BOD}_{5}$ with Temperature; Nitrates with TSS, COD; Phosphate-TSS; Coliform with Temperature had an inverse and weak correlation $(\mathrm{r}<0$ and $\mathrm{r}<0.3$ ). In addition, the pairs of parameters TemperaturePhosphate, DO-Phosphate had absolutely no correlation $(\mathrm{r}=0)$ and the parameter pairs of Temperature-TSS, DO-BOD 5 , BOD 5 -Nitrate, Coliform-TSS, Coliform-Nitrates had no observed significance $(\mathrm{r}<\alpha=5 \%)$.

- In the rainy season: parameters $\mathrm{COD}$ and $\mathrm{BOD}_{5}$ had a strong correlation $(\mathrm{r} \geq 0.5)$. Meanwhile, pair of parameters Temperature-Coliform had an average correlation $(0.3 \leq \mathrm{r}<$ 0.5). Pairs of parameters $\mathrm{pH}-\mathrm{Temperature}$, DO-TSS, COD-pH, $\mathrm{pH}-\mathrm{BOD}_{5}$, NitrateTemperature, Nitrate-DO, Nitrate- $\mathrm{pH}$, Nitrate-COD, Nitrate-BOD 5 , Nitrate-TSS, Phosphate-DO, Phosphate-pH, Phosphate-COD, Phosphate-BOD 5 , Phosphate-TSS had a weak correlation $(r<0.3)$. Pair of parameters $\mathrm{pH}-\mathrm{TSS}$ had an inverse and average correlation ( $r<0$ and $r \geq 0.3$ ) The remaining parameter pairs: DO with $\mathrm{pH}$ and Temperature; TSS with Temperature; COD with Temperature and DO; $\mathrm{BOD}_{5}$ with Temperature and DO; Phosphate with Temperature; Coliform with $\mathrm{pH}$, TSS, $\mathrm{COD}, \mathrm{BOD}_{5}$ and Phosphate had an inverse and weak correlation $(\mathrm{r}<0$ and $\mathrm{r}<0.3$ ). In addition, pair of parameters TSS-BOD 5 had absolutely no correlation $(\mathrm{r}=0)$ and pairs of parameters COD-TSS, Coliform-nitrate had no observable significance $(r<\alpha=5 \%)$.

\subsection{Principal component analysis (PCA)}

\subsubsection{Dry season}

a. Principal component analysis of water quality parameters in the dry season 
In the dry season, the research based on the results of the Scree plot (Figure 10) with the Eigenvalue index $>1.0$ identified the first 4 principal components PC1, PC2, PC3, PC4 with the total variance accounting for $68.6 \%$ of tuples. These 4 components were used for further analysis. From the 5 th components onwards had small variance, so they were ignored.

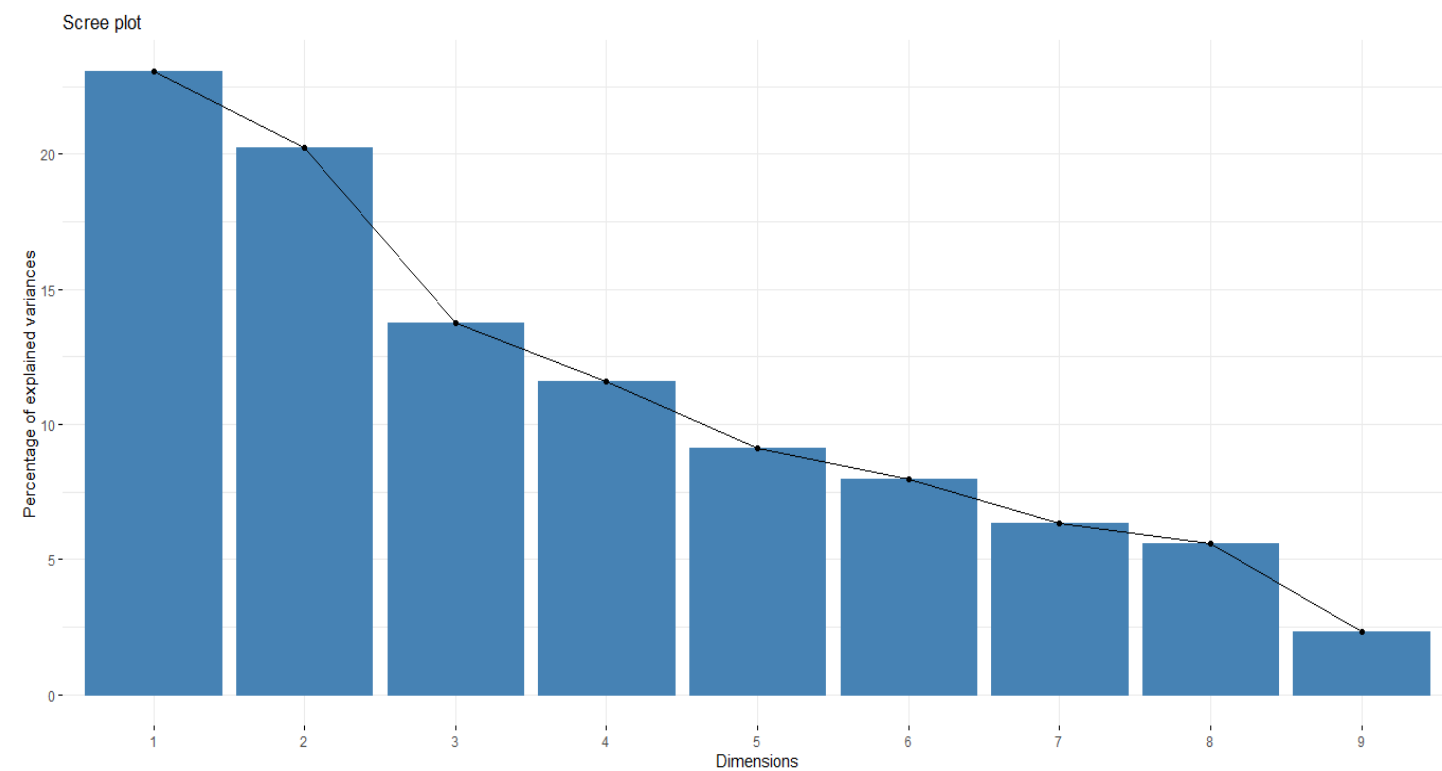

Figure 10. Screen plot analysis of principal components of water quality parameters in dry season.

The main influencing parameters in the principal components PC1, PC2, PC3, PC4 include:

- PC1 had a total variance value of $23.04 \%$, including: COD (positive contribution with rotated component indicator of 0.88 ), $\mathrm{BOD}_{5}$ (positive contribution with rotated component indicator of 0.85 ). The principal group of components showed pollution by organic substances of natural or artificial origin (domestic wastewater, industrial wastewater, agricultural wastewater).

- PC2 had a total variance value of $20.22 \%$, including: DO (positive contribution with rotated component indicator of 0.73 ), $\mathrm{pH}$ (positive contribution with rotated component indicator of 0.69), Coliform (positive contribution with rotated component indicator of 0.65). The principal group of components showed that $\mathrm{pH}$ and dissolved oxygen were correlated with Coliform parameter. From analyzing the correlation of water quality parameters in the dry season, this study showed that Coliform parameter is positively correlated with DO and $\mathrm{pH}$, which means that the increase of $\mathrm{pH}$ and dissolved oxygen increases the Coliform concentration in water.

- PC3 had a total variance value of $13.76 \%$, including: Phosphate (positive contribution with rotated component indicator of 0.76 ), TSS (negative contribution with rotated component indicator of 0.85 ). The principal group of components indicated pollution of suspended solids and phosphates with a inverse correlation, if TSS concentration increases, phosphate concentration decreases and vice versa.

- PC4 had a total variance value of $11.58 \%$, including: Temperature (positive contribution with rotated component indicator of 0.92 ). PC4 showed that the temperature of the water was affected by the environment or the source of the discharge.

b. Pollution characteristics of Hau river in dry season

- Principal components PC1 and PC2

The water quality characteristics of Hau river at the monitoring locations $\mathrm{SH}-\mathrm{T}$ and $\mathrm{SH}-$ $\mathrm{H}$ for PC1 and PC2 in the dry season are shown in Figure 11. 


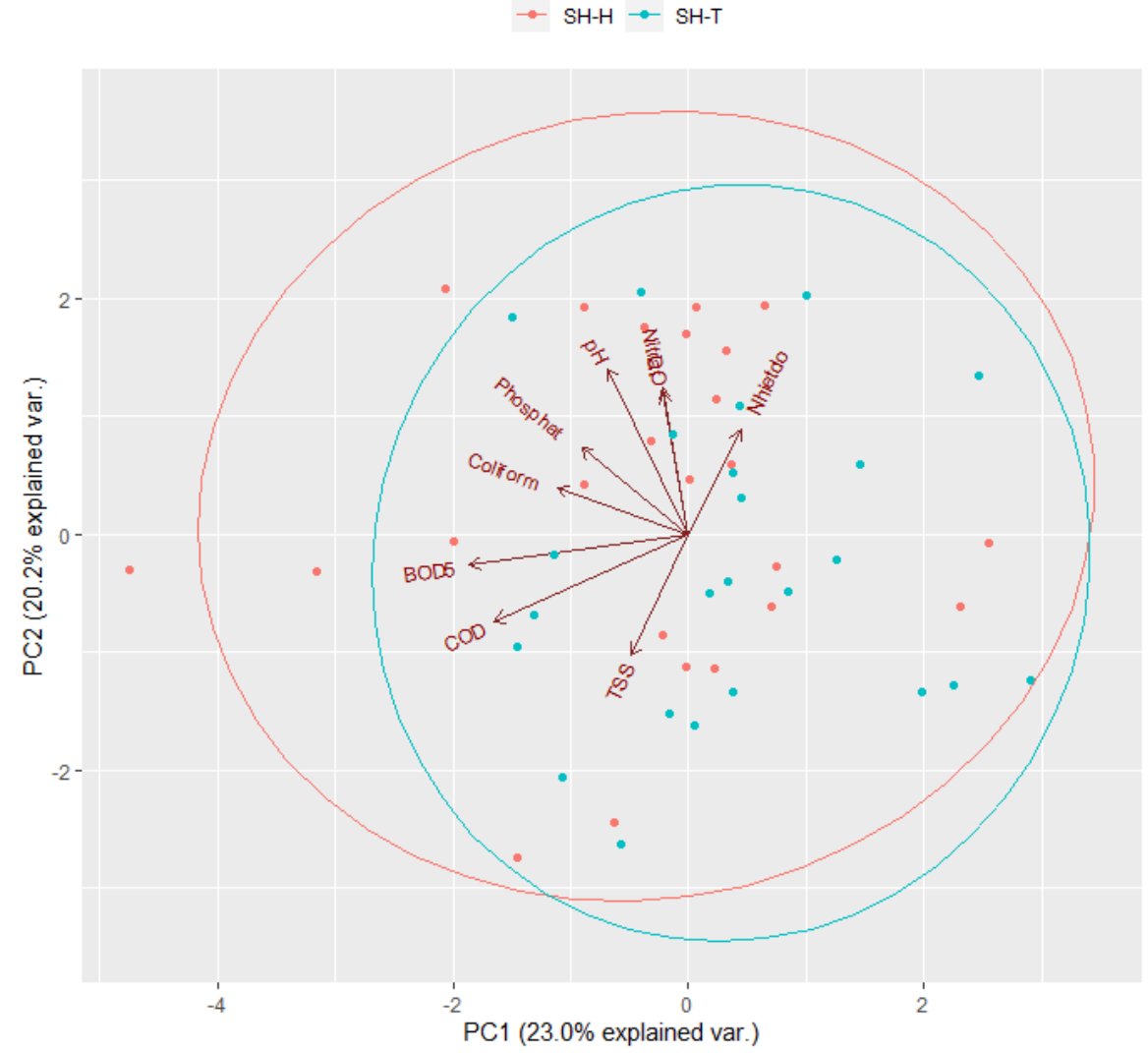

Figure 11. Water quality characteristics of Hau river at monitoring locations $\mathrm{SH}-\mathrm{T}$ and $\mathrm{SH}-\mathrm{H}$ corresponding to PC1 and PC2 in the dry season.

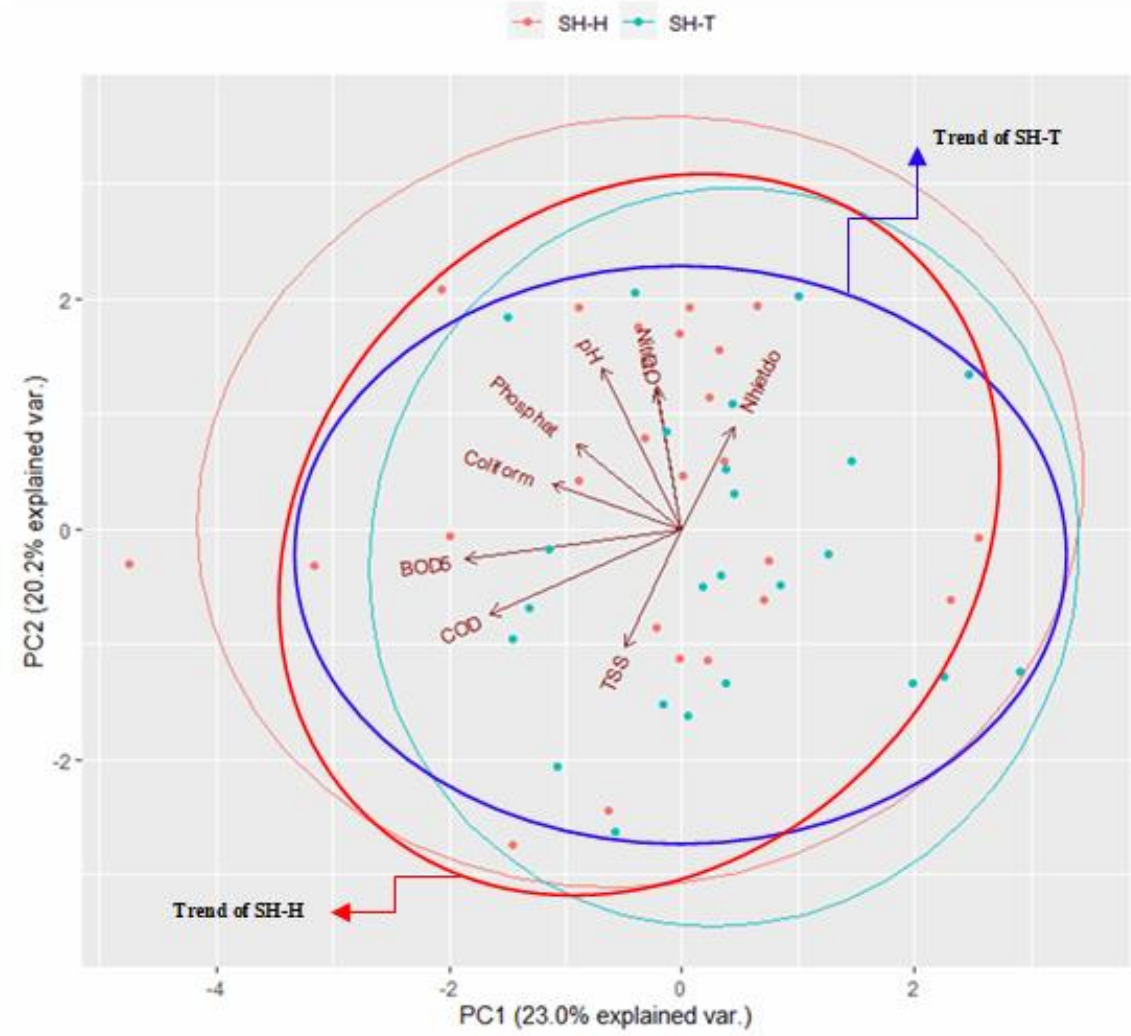

Figure 12. Water quality trends of Hau river at locations $\mathrm{SH}-\mathrm{T}$ and $\mathrm{SH}-\mathrm{H}$ corresponding to $\mathrm{PC} 1$ and PC2 in the dry season. 
Analysis results from $\mathrm{R}$ software showed that: At the monitoring location upstream of Hau river $(\mathrm{SH}-\mathrm{T})$ was characterized by most of the main parameters of $\mathrm{PC} 1\left(\mathrm{COD}, \mathrm{BOD}_{5}\right)$ and PC2 (DO, pH and Coliform); however the main parameters in PC2 (vertical axis) had more influential. At the monitoring location downstream of Hau river $(\mathrm{SH}-\mathrm{H})$ was characterized by most of the main parameters of PC1 (COD, BOD 5$)$ and PC2 (DO, pH and Coliform), however the main parameters in PC1 (horizontal axis) had more influential. However, the research team assessed that the trend of water quality in the upper Hau River ( $\mathrm{SH}-\mathrm{T})$ was influenced by water quality parameters of the principal component PC1 more than PC2. Besides, the trend of water quality in the lower Hau River ( $\mathrm{SH}-\mathrm{H})$ was influenced by water quality parameters of the principal component PC2 (Figure 12). In other words, in the dry season, the $\mathrm{SH}-\mathrm{T}$ position of the river is affected by the parameters of $\mathrm{COD}, \mathrm{BOD}_{5}$ more.

In fact, from the results of sample analysis data and comparison with QCVN 08MT:2015/BTNMT (level A1)-National technical regulation on quality surface water, DO at the location $\mathrm{SH}-\mathrm{T}$ was the lowest in the $4^{\text {th }}$ observation in November and only 04/48 monitoring times had values that the allowed standards. The monitoring results at $\mathrm{SH}-\mathrm{T}$ location showed that the COD concentration were 1.1-2.2 times higher than the allowed standards, the highest pollution value was the 4th observation in November. The values of $\mathrm{BOD}_{5}$ concentration at $\mathrm{SH}-\mathrm{T}$ ranged from $7-14 \mathrm{mg} / \mathrm{l}$, which were 1.75-3.50 times higher than the standard. High $\mathrm{COD}$ and $\mathrm{BOD}_{5}$ concentrations reduced the $\mathrm{DO}$ concentration of the water, which was harmful to water organisms and the water ecosystem in general. Organic wastewater, domestic wastewater and chemical wastewater were the agents that create high $\mathrm{BOD}_{5}$ and $\mathrm{COD}$ values of the aquatic environment. High levels of COD and $\mathrm{BOD}_{5}$ in water showed that the water source contains many organic pollutants. At $\mathrm{SH}-\mathrm{H}$, except for the 4th observation in January and the 1st observation in July, the values of Coliform in the remaining observations were higher than QCVN 08-MT:2015/BTNMT, level A1 (2500 MPN/100 ml) from 1.72-9.60 times.

- Principal components $\mathrm{PC} 3$ và $\mathrm{PC} 4$

The water quality characteristics of Hau river at the monitoring locations $\mathrm{SH}-\mathrm{T}$ and $\mathrm{SH}-$ $\mathrm{H}$ for PC3 and PC4 in the dry season are shown in Figure 13.

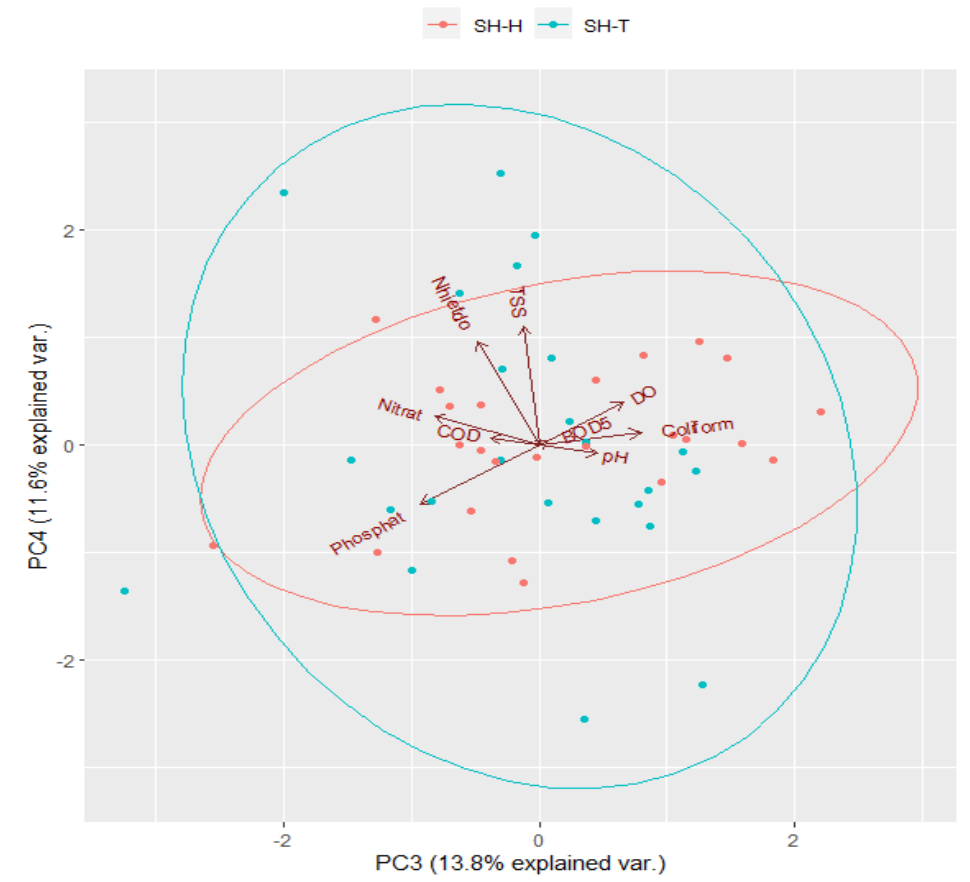

Figure 13. Water quality characteristics of Hau river at monitoring locations $\mathrm{SH}-\mathrm{T}$ and $\mathrm{SH}-\mathrm{H}$ corresponding to PC3 and PC4 in the dry season. 
Analysis results from $\mathrm{R}$ software showed that: At the monitoring loction upstream of Hau river (SH-T) was characterized by most of the main parameters of PC3 (Phosphate and TSS) and PC4 (Temperature), however the Temperature parameter in PC4 (vertical axis) had more influence; At the monitoring location downstream of Hau River $(\mathrm{SH}-\mathrm{H})$ was characterized by most of the main parameters of PC3 (Phosphate and TSS) and PC4 (Temperature), but the main parameters in PC3 (horizontal axis) had more influence. This explains that the water downstream quality of Hau river showed signs of being affected by phosphates and suspended solids. However, the influence of the two principal components PC3 and PC4 will have little apparent effect because PC3 and PC4 account for very small percentages of the total variance of the principal components $(13.8 \%$ and $11.6 \%)$.

\subsubsection{Rainy season}

a. Principal component analysis of water quality parameters in the rainy season

In the rainy season, the research based on the results of the Scree plot (Figure 14) with the Eigenvalue index > 1.0 identified the first 4 principal components PC1, PC2, PC3, PC4 with the total variance accounting for $72.14 \%$ of tuples. These 4 components were used for further analysis. From the $5^{\text {th }}$ components onwards had small variance, so they were ignored. Scree plot

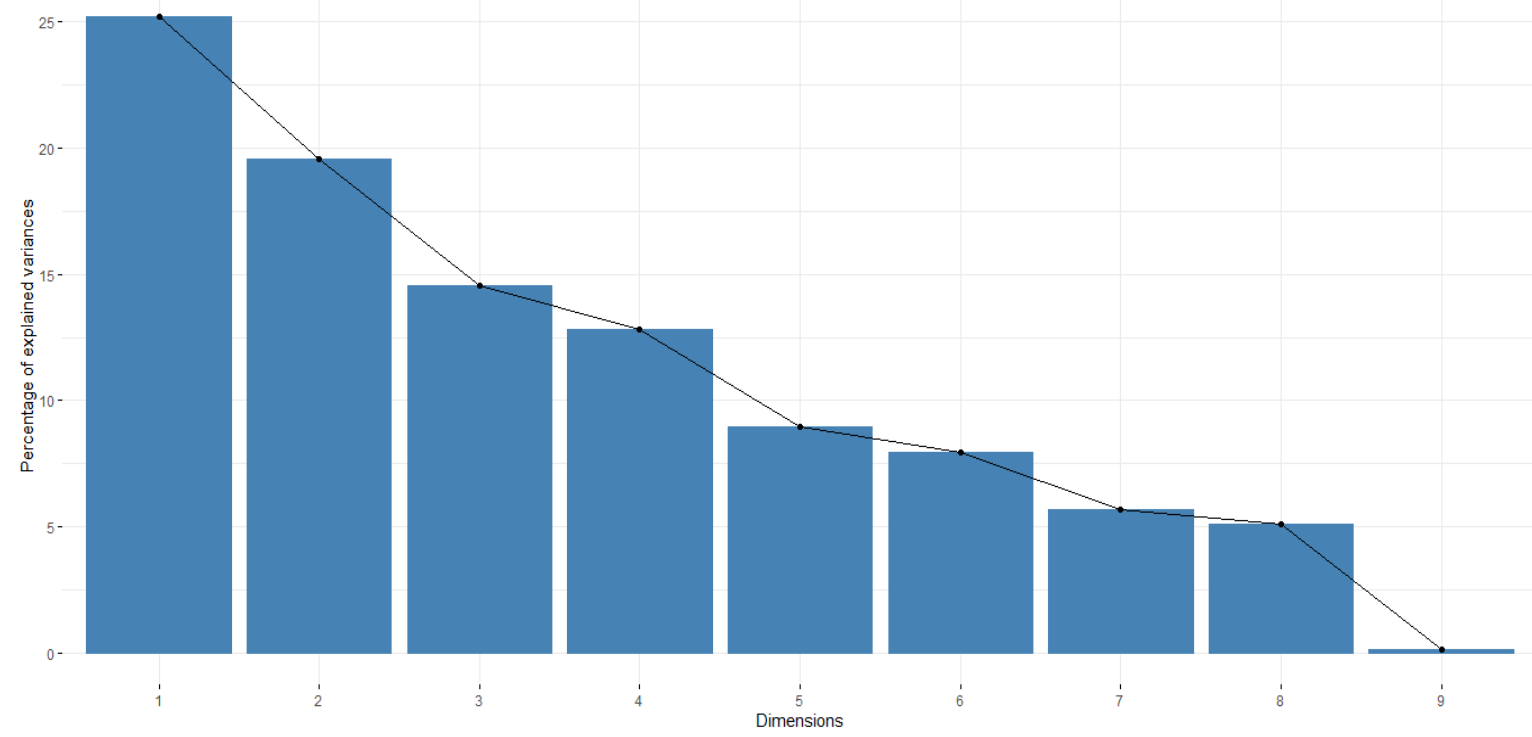

Figure 14. Screen plot analysis of principal components of water quality parameters in rainy season.

The main influencing parameters in the principal components PC1, PC2, PC3, PC4 include:

- PC1 had a total variance value of $25.2 \%$, including: COD (positive contribution with rotated component indicator of 0.98 ), $\mathrm{BOD}_{5}$ (positive contribution with rotated component indicator of 0.97 ). The principal group of components indicated pollution by organic substances of natural or artificial origin (domestic wastewater, industrial wastewater, agricultural wastewater).

- PC2 had a total variance value of 19.6\%, including: $\mathrm{pH}$ (positive contribution with rotated component indicator of 0.82), TSS (negative contribution with rotated component indicator of 0.79 ). The principal group of components showed that the $\mathrm{pH}$ and total suspended solids in the water.

- PC3 had a total variance value of $14.56 \%$, including: Coliform (positive contribution with rotated component indicator of 0.87 ), Temperature (positive contribution with rotated component indicator of 0.73 ). The principal group of components indicated harmful microorganisms that are affected by temperature (parameters Temperature and Coliform had 
an average correlation with $\mathrm{r}=0.33$ (increasing temperature will increase Coliform and vice versa).

- PC4 had a total variance value of $12.82 \%$, including: Nitrat (positive contribution with rotated component indicator of 0.83 ), DO (positive contribution with rotated component indicator of 0.75). PC4 showed that water environment was affected by nitrate and temperature with a rather weak correlation coefficient $(\mathrm{r}=0.08)$.

b. Pollution characteristics of Hau River in rainy season

- Principal components PC1 and PC2

The water quality characteristics of Hau river at the monitoring locations $\mathrm{SH}-\mathrm{T}$ and $\mathrm{SH}-$ $\mathrm{H}$ for $\mathrm{PC} 1$ and PC2 in the rainy season are shown in Figure 15.

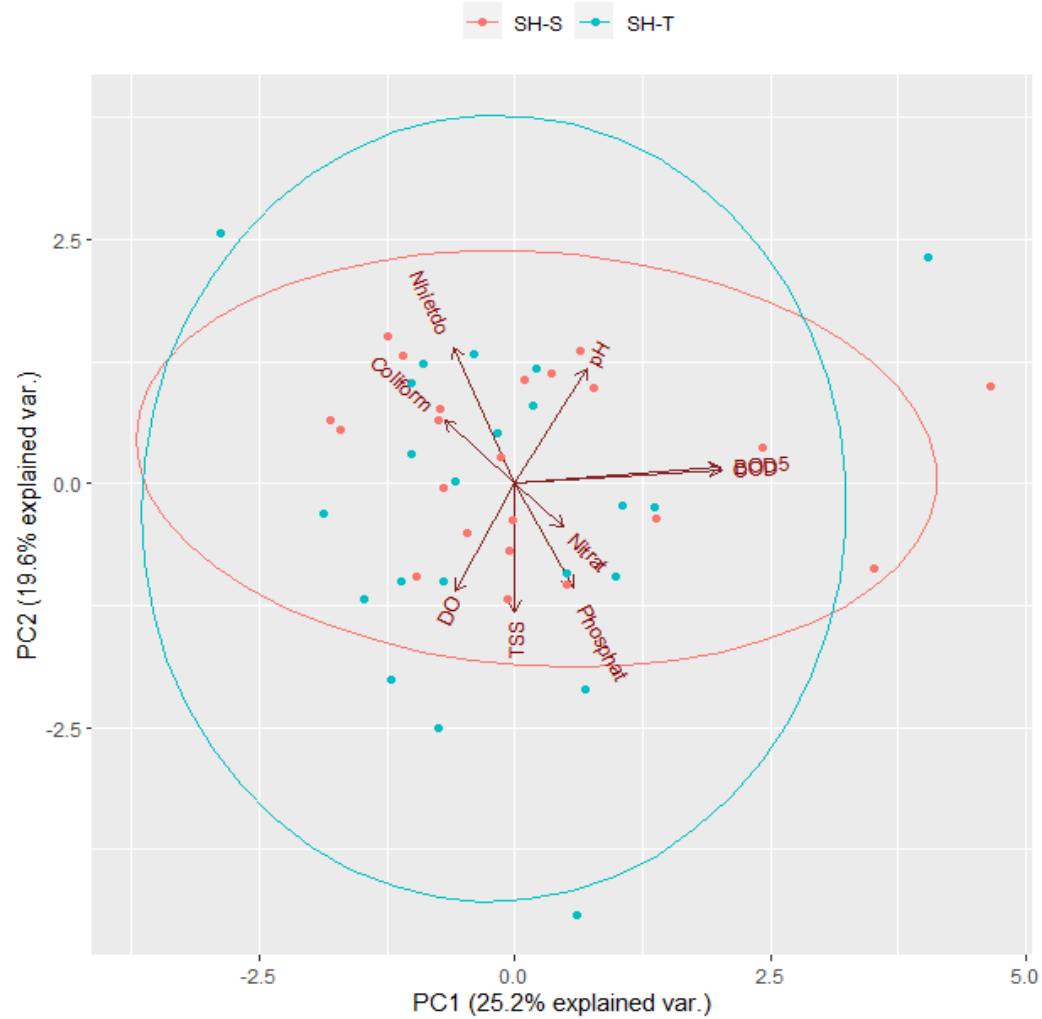

Figure 15. Water quality characteristics of Hau river at monitoring locations $\mathrm{SH}-\mathrm{T}$ and $\mathrm{SH}-\mathrm{H}$ corresponding to PC1 and PC2 in the rainy season.

Analysis results from $\mathrm{R}$ software showed that: At the monitoring location upstream of Hau River (SH-T) was characterized by most of the main parameters of PC1 (COD, BOD 5 ) and PC2 (pH and TSS); however the main parameters in PC2 (vertical axis) had more influence. At the monitoring location downstream of Hau river $(\mathrm{SH}-\mathrm{H})$ was characterized by most of the main parameters of PC1 (COD, BOD 5 ) and PC2 (pH and TSS), but the main parameters in PC1 (horizontal axis) had more influence.

However, the authors assessed that the water quality of Hau river at the upstream location of SH-T influenced very clearly by the principal component PC2 and at the same time had been greatly influenced by principal component PC1 (Figure 16).

In fact, from the results of sample analysis data and comparison with QCVN 08MT:2015/BTNMT (level A1)-National technical regulation on quality surface water, the monitoring results at $\mathrm{SH}-\mathrm{T}$ location showed that the COD concentration by the monitoring times did not reach the allowable standards according to QCVN 08-MT:2015/BTNMT, level A1 $(10 \mathrm{mg} / \mathrm{l})$. The values of $\mathrm{BOD}_{5}$ concentration at $\mathrm{SH}-\mathrm{T}$ ranged from $7-14 \mathrm{mg} / \mathrm{l}$, which were 1.75-3.50 times higher than QCVN 08-MT:2015/BTNMT, level A1 (4 mg/l). 


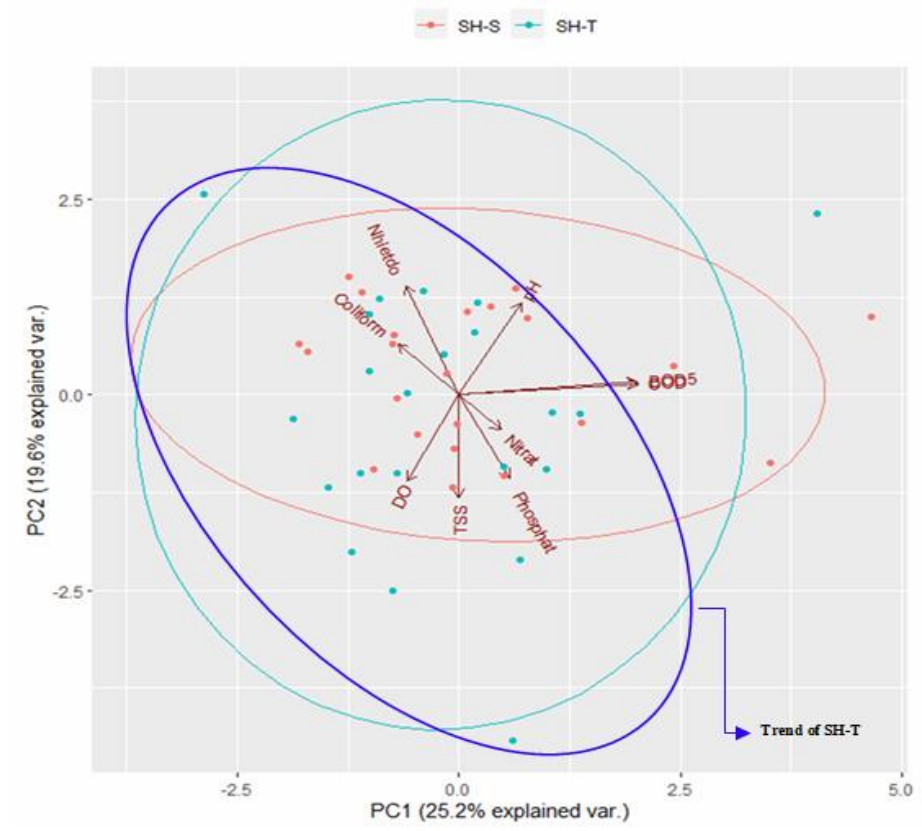

Figure 16. Water quality trends of Hau river at locations $\mathrm{SH}-\mathrm{T}$ and $\mathrm{SH}-\mathrm{H}$ corresponding to $\mathrm{PC} 1$ and $\mathrm{PC} 2$ in the rainy season.

- Principal components $\mathrm{PC} 3$ và PC4

The water quality characteristics of Hau river at the monitoring locations $\mathrm{SH}-\mathrm{T}$ and $\mathrm{SH}-$ $\mathrm{H}$ for PC3 and PC4 in the rainy season are shown in Figure 17. Analysis results from R software showed that: At the monitoring location upstream of the Hau river $(\mathrm{SH}-\mathrm{T})$ was characterized by most of the main parameters of PC3 (Temperature and Coliform) and PC4 (Nitrates and DO), but PC4 (vertical axis) had more influence. In which, parameters DO and nitrate had a weak positive correlation $(\mathrm{r}=0.26)$. At the monitoring location downstream of Hau river $(\mathrm{SH}-\mathrm{H})$ was characterized by most of the main parameters of PC3 (Temperature and Coliform) and PC4 (nitrate and DO), but the main parameters in PC3 (axis diaphragm) had more influence. This explains that the water downstream of Hau river showed signs of being affected by Coliform bacterias; they and Temperature had an average positive correlation $(r=0.33)$.

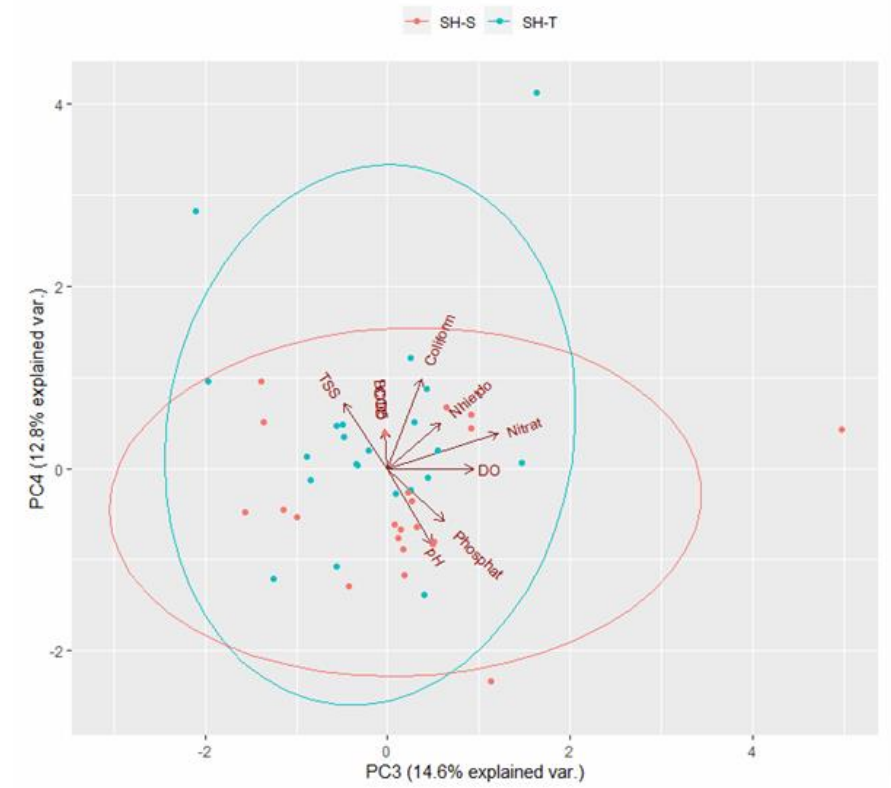

Figure 17. Water quality characteristics of Hau river at monitoring locations $\mathrm{SH}-\mathrm{T}$ and $\mathrm{SH}-\mathrm{H}$ corresponding to PC3 and PC4 in the rainy season. 


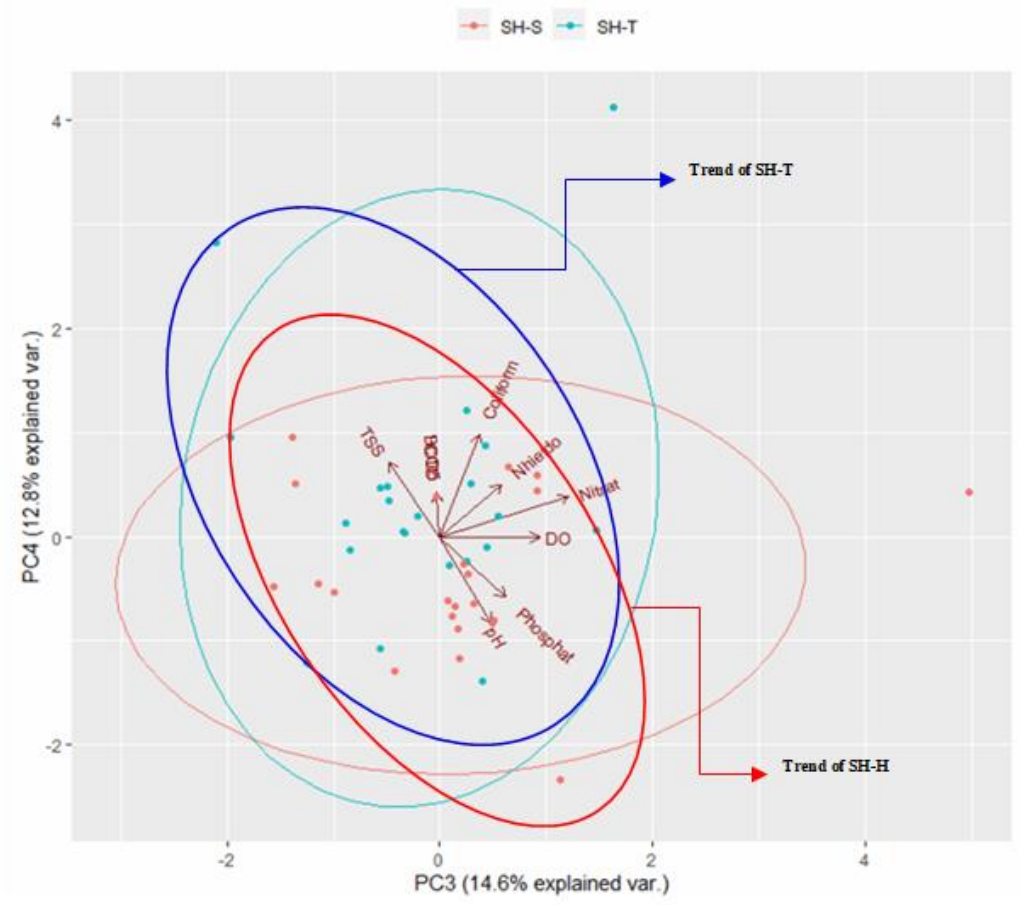

Figure 18. Water quality trends of Hau river at locations $\mathrm{SH}-\mathrm{T}$ and $\mathrm{SH}-\mathrm{H}$ corresponding to $\mathrm{PC} 3$ and PC4 in the rainy season.

The authors assessed that the water quality of Hau river at the upstream location of SH$\mathrm{T}$ influenced very clearly by the principal component PC4 and at the same time had been greatly influenced by principal component PC3. Besides, the trend of water quality in the lower Hau River ( $\mathrm{SH}-\mathrm{H})$ was affected by both principal components PC3 and PC4. However, the influence of the two principal components PC3 and PC4 will have little apparent effect because PC3 and PC4 account for very small percentages of the total variance of the principal components (14.56\% and $12.82 \%)$.

\section{Conclusion}

Surface water quality in the area was continuously monitored at the upstream and downstream locations of Hau river bordering Can Tho in 2019 was not guaranteed well according to QCVN 08-MT:2015/BTNMT (level A1)-National technical regulation on surface water quality. In which, the DO concentrations in the water were lower than the permitted standards and in the polluted state of parameters TSS, COD, $\mathrm{BOD}_{5}$, Phosphate $\left(\mathrm{PO}_{4}{ }^{3-}\right.$ by $\left.\mathrm{P}\right)$, Ammonium $\left(\mathrm{NH}_{4}{ }^{+}\right.$by $\left.\mathrm{N}\right)$ and especially Coliform bacteria.

The results of two monitoring sessions on zooplankton in the upper Hau river location (SH-T) in 2019 showed that the water quality according to diversity index H' was in a polluted state; Surface water quality ranges from "Heavily polluted" to "Moderately polluted" according to the diversity index $\mathrm{H}^{\prime}$ of the zooplankton parameters. This once again proved that the assessment of water quality according to the diversity index $\left(\mathrm{H}^{\prime}\right)$ was quite similar to the results of the assessment of water quality according to the physicochemical parameters.

Besides, the results of statistical analysis on the difference of physico-chemical parameters data in the 2 rainy and dry seasons showed the difference of 3 parameters Coliform, TSS, Nitrate in 2 real seasons was caused by environmental conditions (had statistically significant). This results showed that the water quality of Hau river was affected by these parameters and the cause may be due to natural origin such as erosion, geological structure or under the influence of other activities, human activities, production, untreated wastewater, excessive agricultural production, etc. Because they had caused many bad 
impacts leading to water pollution due to the decomposition of organic compounds muscle, high concentration of coliform bacteria in water; TSS concentration in water is mainly affected by the amount of alluvium from upstream, plus a large amount of soil, rock, wastes washed into the river by stormwater runoff, contributing to a significant increase in TSS concentration. This result also corresponds to the results of direct analysis of water quality parameters and is compared according to QCVN 08-MT:2015/BTNMT, level A1.

The results of analysis of main components of water quality parameters in space (SH-T and $\mathrm{SH}-\mathrm{H}$ ) and over time (dry season and rainy season) showed that water quality in Hau river tended to be polluted by $\mathrm{COD}, \mathrm{BOD}_{5}$ and Coliform. In the rainy season, the water quality of Hau River was affected by these parameters more than in the dry season. In addition, according to the results of the correlation analysis: In the dry season, the pair of parameters $\mathrm{COD}$ and $\mathrm{BOD}_{5}$ had a strong correlation $(\mathrm{r} \geq 0.5)$, $\mathrm{BOD}_{5}-$ Coliform had an average correlation $(0.3 \leq \mathrm{r}<0.5)$; In the rainy season, $\mathrm{COD}$ and $\mathrm{BOD}_{5}$ parameters had a strong correlation $(r \geq 0.5)$, pair of parameters Temperature-Coliform have an average correlation $(0.3 \leq \mathrm{r}<0.5)$. This result showed the mutual influence and correlation between pollution parameters that the Hau river water quality at $\mathrm{SH}-\mathrm{T}$ and $\mathrm{SH}-\mathrm{H}$ tended to be affected by. The analysis results also showed that in the rainy season, water quality was more affected by these than in the dry season.

Therefore, it is recommended that people living along the river should not use it directly, it is necessary to treat the water thoroughly before putting it into use to ensure long-term health.

Authors contribution: Contructing reseach idea: H.P., N.L.N.T.; Select research methods: H.P., N.L.N.T., H.T.N.H.; Data processing: H.P., N.L.N.T., H.T.N.H.; Sample analysis: N.L.N.T., T.N.N.; Take samples: H.P., N.L.N.T., T.N.N.; Writing original draft preparation: H.P., H.T.N.H.; N.L.N.T; Writing review and editing: H.P., H.T.N.H., N.L.N.T.

Acknowledgments: This article was completed from the results of the research project on water quality of Hau river flowing through An Giang province.

Conflicts of Interest: The authors declare that this article was the work of the authors, has not been published elsewhere, has not been copied from previous research; there was no conflict of interest within the author group.

\section{References}

1. Wikipedia. Key economic region in the Mekong Delta region. https://vi.wikipedia.org/wiki/V\%C3\%B9ng_kinh_t\%E1\%BA\%BF_tr\%E1\%BB\%8 Dng_\%C4\%91i\%E1\%BB\%83m_v\%C3\%B9ng_\%C4\%91\%E1\%BB\%93ng_b\%E1 \%BA\%B1ng_s\%C3\%B4ng_C\%E1\%BB\%ADu_Long (In Vietnamese).

2. Luu, P.T. Using water quality index (WQI) and the biological diatom index (BDI) for assessment of the water quality in the Sai Gon River. Ho Chi Minh City Univ. Educ. J. Sci. 2020, 17(9), 1558-1596. (In Vietnamese)

3. Lien, N.T.K. Research on biological monitoring methods in assessing water quality on Hau river route using large invertebrates. $\mathrm{PhD}$ thesis in aquaculture, 2017.

4. Boyd, C.E. Water quality for pond Aquaculture. Deparment of Fisheries and Allied Aquacultures. Auburn University, Alabama 36849 USA, 1998, pp. 37.

5. Quyen, L.C. Distribution of phytoplankton in Bung Binh Thien, An Giang. Sci. J. An Giang University 2015, 7(3), 66-74.

6. Cat, L.V.; Nhung, D.H.; Cat, N.N. Quality aquaculture water and quality improvement solutions. Science and Technology Publishing Company, Hanoi, 2006, pp. 424.

7. Ba, L.H. Soil environment ecology. Ho Chi Minh City National University Publishing Company, 2007, pp. 320. 
8. Linh, L.T.N.; Hung, P.Q. Current status of exploitation and protection of inland aquatic resources in An Giang province. J. Fish. Sci. Technol. 2015, 2, 47-49.

9. Nguyen, P.Q.; Y, L.H.; Cong, N.V.; Phu, T.Q. Evolution of some water quality parameters in intensive cultured catfish (Pangasianodon hypophthalmus) ponds. Scie. J. Can Tho Univ. 2014, 34, 128-136.

10. Thuong, P.V.; Bach, D.D. Textbook of environmental chemistry, Hanoi Science and Technology Publishing Company, 1999, pp. 231.

11. Department of Natural Resources and Environment of An Giang province, 5-year environmental status report of An Giang province for the period 2005-2009, 2012, pp. 152.

12. Tri, T.N.; Dat, H.D.; Sang, N.V. Research on the biodiversity of fish fauna in Bung Binh Thien wetland, An Giang province. J. Biol. 2012, 34, 21-29.

13. Nguyen, T.T. Fluctuations in water quality in Hau river. Master thesis, Faculty of Fisheries, Can Tho University, 2013, pp. 70.

14. Phu, T.Q.; Yi, Y. Effects of catfish farming in rafts on water quality in Hong Ngu district, Dong Thap province. Sci. J. Can Tho Univ. 2005, 3, 8-17.

15. Van, L.T.H.; My, T.N.D. Survey of phytoplankton composition and surface water quality at some points around aquaculture areas in some Ben Tre provinces. J. Sci. Technol. Dev. Fac. 4(1), 401-411.

16. Ty, D.V.; Huy, N.H.; Da, C.T.; Ut, V.N.; Viet, T.V. Assessment of water quality changes in Bung Binh Thien, An Giang province. Can Tho Univ. Sci. J. 2018, 54(3), 125-131. Doi:10.22144/ ctu.jvn.2018.048.

17. Dung, T.D.; Quan, N.Q.; Hue, N.T.T.; Luan, P. Evaluation of water quality in La Buong river by method multivariate statistics over space and time. $V N J$. Hydrometeorol. 2021, 731, 36-53. Doi:10.36335/VNJHM.2021(731).36-53.

18. Climatology and Hydrology Research Centre. Department for Geography, Tourism and Hotel Management. Statistical analysis of water quality parameters of veliki bački canal (vojvodina, serbia) in the period 2000-2009. Carpathian J. Earth Environ. Sci. 2012, 7(2), 255-264.

19. Hung, N.T.Q.; Dang, D.H.; Thai, P.V.; Ky, N.M.; Tuan, H.N.A. Research and assessment of water use and quality level of living in Trang Bang district, Tay Ninh province. VNU Sci. J. Earth Environ. Sci. 2018, 34(4), 10-21.

20. Au, N.H.; Ngan, P.T.K.; Thuy, H.T.T.; Ngoc, P.N.H. Aplication of multivariate statistical analysis in Evaluation of underground water quality Tan Thanh district, $\mathrm{Ba}$ Ria - Vung Tau province. Sci. Technol. Dev. 2017, 20, M2-2017. 